\title{
REDONDELA Y VIGO FRENTE A LA LUCTUOSA Y EL DIEZMO ECLESIÁSTICO: LA SENTENCIA ARBITRAL DE 1494
}

\author{
Por \\ JOSÉ MARTÍNEZ CRESPO
}

La «Sentencia Arbitral» de 1494 es un interesante documento inédito cuyo conocimiento ha sido posible gracias a la amabilidad de D. Alejandro Martínez Adán y de D. Manuel Puga Pereira, quienes lo rescataron y preservaron tras haber formado parte, al parecer, de un grupo documental (seguramente de época medieval) contenido en un baúl perteneciente a la iglesia de Redondela.

Tal documentación, tras largo tiempo en manos de particulares y quizá debido al desconocimiento de su valor y a su posible deterioro, terminó por ser desgraciadamente destruida, quedando dicho documento casi como único testimonio.

El manuscrito que aquí se presenta viene a ser la posterior copia y recopilación de los varios o el total de los documentos que compusieron el pleito y sentencia que se derivó del conflicto planteado por los vecinos de Redondela, Reboreda y Vigo a causa de algunos derechos que debían satisfacer a los rectores de las iglesias de sus respectivas feligresías. Los escritos forman entre todos dos partes diferenciadas cronológicamente: La primera, compuesta por un grupo de siete documentos fechados entre Julio y Agosto de 1494, y la segunda, constituida por un último documento, el octavo, datado en Abril de 1516.

Este conjunto documental está compuesto por siete hojas sin foliar escritas por ambas caras en letra humanística, probablemente de finales

"CUADERNOS DE ESTUDIOS GALLEGOS", Tomo XLVII, Fascículo 113, Santiago 2000. 
del s. XVI o principios del XVII ${ }^{1}$, época en que se hizo la copia. Sus medidas son $312 \times 220 \mathrm{~mm}$. aproximadamente. Para facilitar su lectura se han eliminado los enlaces innecesarios entre palabras y se ha modificado parcialmente la algo confusa puntuación. También se han individualizado cada uno de los documentos que integran el conjunto (en el original separados tan solo por dos puntos y aparte el primero y por un signo $=$ los restantes), colocándolos después de punto y aparte y doble espacio de margen. Por lo demás, se ha respetado la estructura del texto y la forma original de las palabras. Como peculiaridad, el texto está escrito en gallego o castellano según las partes, salvo el pequeño anexo de 1516, escrito íntegramente en castellano.

Dentro de la unidad que constituye este conjunto, podemos dividirlo, a efectos de una más fácil comprensión y un mejor análisis, en ocho secciones, correspondientes a casi otros tantos documentos, que se pueden sintetizar así:

a) 1494, Agosto, 24. Tuy. Reunión y presentación de las partes litigantes: la eclesiástica y la de los vecinos de Redondela y Vigo, representados por sus procuradores.

b) 1494, Agosto, 19. Tuy. Carta de Poder y Procuración del rector de la iglesia de Santiago de Redondela, Pai Gomes de Soto, al canónigo Morgued Juan, Provisor y Vicario del Obispo de Tuy D. Pedro Beltrán y rector del Beneficio de Santa María de Reboreda.

c) 1494, Agosto, 20. Vigo. Carta de Poder y Procuración dada por Jacome Perez, rector de la iglesia de Santa María de Vigo, a Rodrigo Afonso, clérigo y criado suyo.

d) 1494, Julio, 27. Vigo. Carta de Poder y Procuración que los mareantes, vecinos y moradores de la Villa de Vigo, dan a Afonso de Fornelos, vecino de la misma.

e) 1494, Julio, 20. Redondela. Carta de Poder y Procuración de los vecinos y moradores de la Villa de Redondela a Juan Cremenco, igualmente vecino de la villa.

f) Compromiso de todas las partes implicadas de aceptar el arbitrio y la sentencia del Obispo de Tuy en todo cuanto él disponga.

${ }^{1}$ Agradezco al Padre D. José García Oro, profesor del Departamento de Paleografía de la Facultad de Geografía e Historia, sus amables indicaciones al respecto.

"CUADERNOS DE ESTUDIOS GALLEGOS", Tomo XLVII, Fascículo 113, Santiago 2000. 
g) Sentencia del Obispo aboliendo el pago de los panos e camas (una especie de luctuosa), que los vecinos debían pagar a sus abades y causa del conflicto, pero reafirmando la obligación del pago de los diezmos (y otros derechos en su caso) en la forma y cuantía que se determinan.

h) 1516, Abril, 26. Redondela. Reclamación presentada por Payo Gomez de Sotomayor, Arcediano de Miñor y rector de las tres cuartas partes «con cura $\rangle^{2}$ de la iglesia de Redondela, ante el juez, regidores, procuradores, vecinos y mareantes de la villa (reunidos en el templo, asistiendo a la Misa Mayor), exigiendo que se cumpla la sentencia dada veintidós años atrás. (Anexo cronológicamente posterior, pero unido al conjunto textual y escrito con la misma letra).

Esta última parte viene a ser como un epílogo de la sentencia, ya que nos descubre la poca voluntad de los mareantes redondelanos a la hora de cumplir el veredicto, aunque éste fue acatado a la postre, ya que todavía seguía vigente en el siglo XVIII ${ }^{3}$.

${ }^{2}$ El curato de una parroquia podía dividirse en dos beneficios: «con cura» $\mathrm{y}$ «sine cura» (o «sin cura»). El primero tenía a su cargo la «cura de almas», es decir, la obligación de celebrar los cultos y enseñar el Evangelio, percibiendo los estipendios y rentas correspondientes. El segundo no tenía tales obligaciones, aunque en alguna ocasión pudiera compartir algunas funciones, pero recibía igualmente parte de las rentas, que se distribuían proporcionalmente entre ambos y sus patronos en función de su participación.

En la Vilanova de Redondela, a lo largo del siglo XIV y hasta mediados del siglo XV, por lo menos, era el arzobispo de Santiago quien poseía el derecho de presentación de todo el beneficio de su iglesia, en la que tenía también una renta anual de 50 sueldos leoneses. (A.H.D.S. Libro Registro de los Bienes y Rentas de la Mitra, fols. 31, 60, 74, 76, 80, 90...).

Sin embargo, Payo Gómez era en 1494 rector de las 3/4 partes con cura de la iglesia de Redondela, la $1 / 4$ sin cura restante pertenecía al Beneficio del patronato real del obispo de Tuy ( según el Sínodo de 1528), recibiendo éste además, la renta de los 50 sueldos leoneses. (SYNODICON HISPANUM. Tomo I (Galicia), dirigido porA. GARCÍA GARCÍA. Biblioteca de Autores Cristianos. Madrid, 1981, págs. 483 y 501, Constituciones de D. Diego de Avellaneda de 1528). Entre mediados y finales del siglo XV pudo producirse -no sabemos en que circunstancias- una cesión o permuta de esa parte de los derechos del arzobispo de Santiago en favor del obispo de Tuy.

${ }^{3}$ «En 24 de Abril de 1789, ante el Escribano D. Pedro de Lago, los marineros de la Villa confiesan y declaran la costumbre de diezmar de todo pescado de quinze uno, ya con redes, artes y facturas, ya con otros instrumentos que tengan y puedan imaginar, conforme lo previene ya una transacción y sentencia arbitraria de 24 de Agosto de 1494 en que se afirman y ratifican». (Museo de Pontevedra. Col. Sampedro, C. 91.20).

"CUADERNOS DE ESTUDIOS GALLEGOS", Tomo XLVII, Fascículo 113, Santiago 2000. 
El conflicto se plantea, por tanto, debido a la resistencia de los vecinos de las villas de Vigo, Redondela y feligresía de Reboreda, a satisfacer el pago de los llamados panos e camas, rroupas de bestir o rroupa de cama, e pano de menefesto, los cuales avia e tenia de costumbre de dar a las Yglessias assi hombres como mugeres, al tiempo de su falecimento onde heran Parrochianos y a la necesidad de establecer claramente el dizimo de pescado, e del pan, vino, e primicias e dizimos personales e otras derechuras que los dichos conzejos e freigreses, de las dichas villas de Vigo, $e$ Redondela, heran obligados de pagar e pagavan a las dichas Yglessias e rectores delas, e a la Yglessia de Tuy assi de derecho Divino como de costumbre en cada un ano...

Las ropas de cama, los paños de luto e incluso la ropa de vestir de los difuntos se llevaban y pagaban a algunas iglesias en concepto de reconocimiento del señorío eclesiástico y también en razón de la confesión sacramental o menefesto (manifiesto). Suponían una renta suficientemente gravosa para los feligreses, que debían hacer frente a tal gravamen en un momento especialmente delicado por la pérdida de un ser querido, de ahí la denominación de «luctuosa». Se obligaba así a los feligreses a desprenderse de unos bienes susceptibles de reutilización y que, en cualquier caso, resultaban necesarios y costosos de reemplazar.

La luctuosa era un impuesto señorial, de clara raíz feudal, ligado al reconocimiento del señorío jurisdicional, o sea, del dominio directo que un señor ejercía sobre los habitantes de un territorio. Aunque no es este el caso, los campesinos dependientes lo pagaban a través de los foros, relación contractual que les obligaba a satisfacer una serie de tributos y prestaciones además de la renta estipulada por el uso de la tierra. En este ámbito, la luctuosa gravaba el derecho de transmisión a los sucesores de los bienes aforados cada vez que se producía el fallecimiento de sus titulares, e igualmente simbolizaba el reconocimiento del señorío por parte del heredero y nuevo titular.

Solía exigirse el mejor animal que se tuviera o un pago en metálico, y si bien esta exacción la percibían los señores únicamente de sus vasallos, es decir, aquellos campesinos sujetos a su señorío jurisdicional, se llegó a exigir también en algunos contratos de foro o subarriendo realizados a foreros que no tenían esa condición. Esto era debido a que muchas veces los señores, tanto laicos como eclesiásticos, trataban de mezclar el señorío territorial (dominio sobre la tierra) con el jurisdicional (dominio sobre los hombres)-siempre apetecido-, aún cuando no les correspondiera este derecho. 


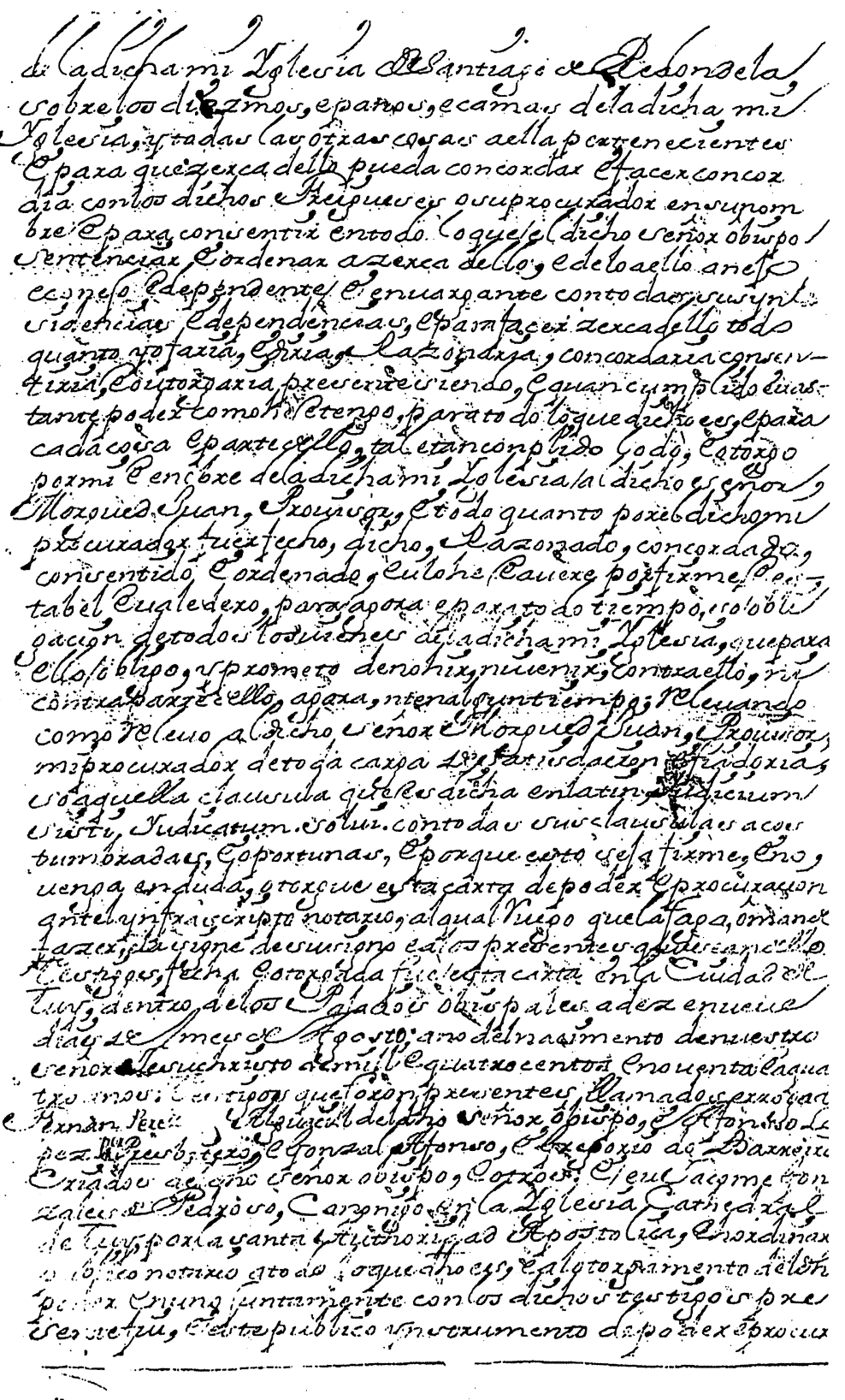

Hoja de la Sentencia Arbitral de 1494. 
La luctuosa era un práctica de la que no se libraban ni los propios clérigos (incluidos los canónigos de la Catedral), ordenándose que se llevara y pagara de cada uno el objeto, ropa o animal lo mejor que toviere ${ }^{4}$. Los Monasterios también percibían la luctuosa, tanto de sus campesinos (e incluso de clérigos foreros), como de los clérigos fallecidos de las iglesias situadas bajo su jurisdicción.

Según las Constituciones de Don Pedro Beltrán, redactadas seguramente antes de 1497 (no se sabe la fecha con exactitud), en unas feligresías se pagaba luitosa e cama e panno de la Yglesia, mientras que en otras solo el panno e cama ${ }^{5}$, caso de las feligresías de Redondela y Vigo. Esto parece dar a entender que el pago de dichos paños y camas no excluía en algunos lugares otro tipo de pago en concepto de luctuosa ${ }^{6}$.

El Diezmo, en cambio, era un pago universal e ineludible -salvo especiales excepciones- cuyo origen se encuentra en laAlta Edad $\mathrm{Media}^{7}$. Era un verdadero impuesto religioso que todos los cristianos, independientemente de su situación social o jurídica, debían a Dios mediante las iglesias de las que eran feligreses, contribuyendo al mantenimiento del culto y de sus servidores.

${ }^{4}$ SYNODICON HISPANUM. Tomo I (Galicia), dirigido por A. GARCÍA GARCÍA. Biblioteca de Autores Cristianos. Madrid, 1981, pág. 375 (Constituciones de D. Diego de Muros) y 483-484 (Sínodo de D. Diego de Avellaneda).

${ }^{5}$ Ibidem. Págs. 386-387. Aunque están sin fecha, estas Constituciones parecen anteriores a las de 1497 , pero son posteriores a 1487, año en que D. Pedro Beltrán comienza su pontificado.

${ }^{6}$ Así opina también SÁNCHEZ CARRERA, M.C.: El Bajo Miño en el siglo XV. El espacio y los hombres. Fundación Pedro Barrié de la Maza. A Coruña, 1997.

${ }^{7} \mathrm{Su}$ origen remoto se encuentra en las prescripciones bíblicas y la religión judaica. En el mundo cristiano, tras ciertos titubeos en los que tan solo se recomienda el pago diezmal, este se hace obligatorio en la segunda mitad del siglo VI, a partir del Concilio Turonense II (año 567) y el Masticonense II (585), que lo impone bajo pena de excomunión. El Concilio IV de Toledo (633) habla también de esta práctica. Más tarde, el mundo musulmán aportó otro ejemplo favorable con el diezmo o «zakal», que la comunidad islámica percibía de los frutos de las cosechas, ganados y mercancías.

La generalización del diezmo universal y obligatorio como ley civil en los reinos castellanos fue obra de Alfonso X el sabio en sus Códigos del Fuero Real (1255) y las Partidas (1265). Estas disposiciones del monarca se explican por el uso político que el rey hizo de estos recursos, que en parte convirtió en un elemento importante del fisco regio y en un ingreso ordinario de la Hacienda Real. Acerca de este y otros aspectos sobre el diezmo, BARREIRO SOMOZA, J. y EIRAS ROEL, A.; voz «Diezmos» en Gran Enciclopedia Gallega. Tomo IX (1974), págs. 109-115. 
Como su nombre indica, gravaba en torno al $10 \%$ de todos los productos y ganancias obtenidas durante un año, cualquiera que fuera su procedencia agraria, ganadera, industrial o comercial. En los ámbitos pesqueros, tanto en los puertos señoriales como en los de realengo, se traducía en una porción de los frutos del mar extraídos por los mareantes, pescadores y mariscadores, o bien su equivalente en dinero.

Los llamados diezmos prediales recaían sobre los productos agrícolas (tanto de las tierras cultivadas desde antiguo como de las de roturación reciente) y sobre el ganado. El derecho canónico, a través de las Constituciones diocesanas, establecía que debían pagarse en la parroquia en la que dichos predios o heredades estaban situados ${ }^{8}$.

El diezmo sobre el ganado debía repartirse, en el caso de que pastara en parajes diversos en las diferentes estaciones, entre las distintas parroquias en cuyos límites soliese pacer, pero no en los lugares de tránsito. Cuando no era así, lo normal era que del ganado que naciese o apacentase fuera de su parroquia se pagase la mitad en la parroquia donde había nacido y la otra mitad en la del lugar donde vivía o pastaba9.

Si bien las actividades económicas de la villa de Redondela eran, en general, de tipo urbano, algunos vecinos -al igual que en las otras villas y ciudades- se dedicaban al laboreo de la tierra o complementaban sus tareas artesanales, pesqueras, e incluso administrativas, con las agrícolas, mediante las explotaciones que poseían o aforaban en el espacio circundante. Estos vecinos, lo mismo que el resto de los campesinos, estaban obligados a pagar los dizimos de pan e vino, e ganado, lino, lana; e otras cosas de la tierra que so dizimos prediales, en la lógica proporción de diez uno, como siempre pagaron. Sin embargo, se establecía una distinción entre los habitantes del área rural y los vecinos de la villa, ya que todos debían pagar dicha proporción salvo los Freigueses de fuera de la Villa de Redondela, de las dichas Yglessias de Santa María de Revoreda e de Santiago de Redondela, porque quasi todos son labradores que estes paguen con el dizimo predial la primicia de quarenta uno del pan.

\footnotetext{
${ }^{8}$ Otrosi ordenamos y mandamos que los diezmos personales se paguen en las parrochas donde se ganaren, y los pedriales (sic) donde se cogen y estan en las heredades, aunque se lleve a otro lugar a mallar, si no uviere concordia en contrario. SYNODICON HISPANUM, op. cit., pág. 476.

${ }^{9}$ Ibidem, pág. 477.
}

"CUADERNOS DE ESTUdiOS GALLEGOS", Tomo XLVII, Fascículo 113, Santiago 2000. 
La primicia (o más bien las primicias) era otra de las prestaciones debidas a la Iglesia que solía acompañar al diezmo, cuyo origen compartía, gravando los mismos productos. Como su nombre indica, consistía en la entrega de los frutos primeros de la tierra o las primeras crías de los animales. Podía estipularse en metálico, aunque generalmente se pagaba en especie, sobre todo en el caso del pan o cereal.

Para evitar fraudes, se ordenaba que los productos no se llevasen de los campos sin avisar previamente al cura, para que éste o su mayordomo o cogedor de los mismos los pudiesen ver partir y diezmar. Es más, si se hallaban ausentes, el feligrés debía intentar localizarlos haciendo tañer y repicar la campana de la iglesia. Si aún así no acudiesen, estaba obligado a llamar a dos hombres buenos para que, como testigos, lo viesen diezmar ${ }^{10}$.

En la feligresía Reboreda, alrededor de esos años (sobre 1506) y muy cerca de la villa de Redondela, existía un lugar llamado Fonte dos dizimos, donde posiblemente se hacía entrega de los productos diezmados de la zona" ${ }^{11}$.

Los dizimos personales e ganadios se establecían sobre las utilidades de la industria y la mano de obra (negocios e industrias, sueldos y salarios, abogacía y procuración, canteras, minas, molinos, etc.). Como en los demás casos, se debían también a la condición de ser miembro de una determinada feligresía y de recibir los sacramentos en ella. Habían de pagarse al párroco aunque el feligrés se hubiera visto obligado a ausentarse. No obstante, las Constituciones de la diócesis tudense ordenaban que estos diezmos gananciales se pagasen en la parroquia donde se ganaran ${ }^{12}$.

Los diezmos personales eran más difíciles de controlar y cuantificar, se encontraban más sujetos a la «buena voluntad» del feligrés; por eso, en la sentencia, se ordena que todos unos e los otros, paguen como siempre pagaron sub cargo de suas conciencias; assi os de Vigo como os de

\footnotetext{
${ }^{10}$ Ibidem.

${ }^{11} 1506 / 02 / 28$. El Monasterio de Santo Domingo de Pontevedra afora a Bartolomé Barro, vecino de Redondela, una viña en la feligresía de Santa María de Reboreda que entesta en outra vinna que labra agora Grigorio de Junqueyras e jaz junto da fonte dos dizimos... (A.R.G. Pergamino original. Sección X (Diplomas), pieza 471).

${ }^{12}$ SYNODICON HISPANUM, pág. 476.
} 


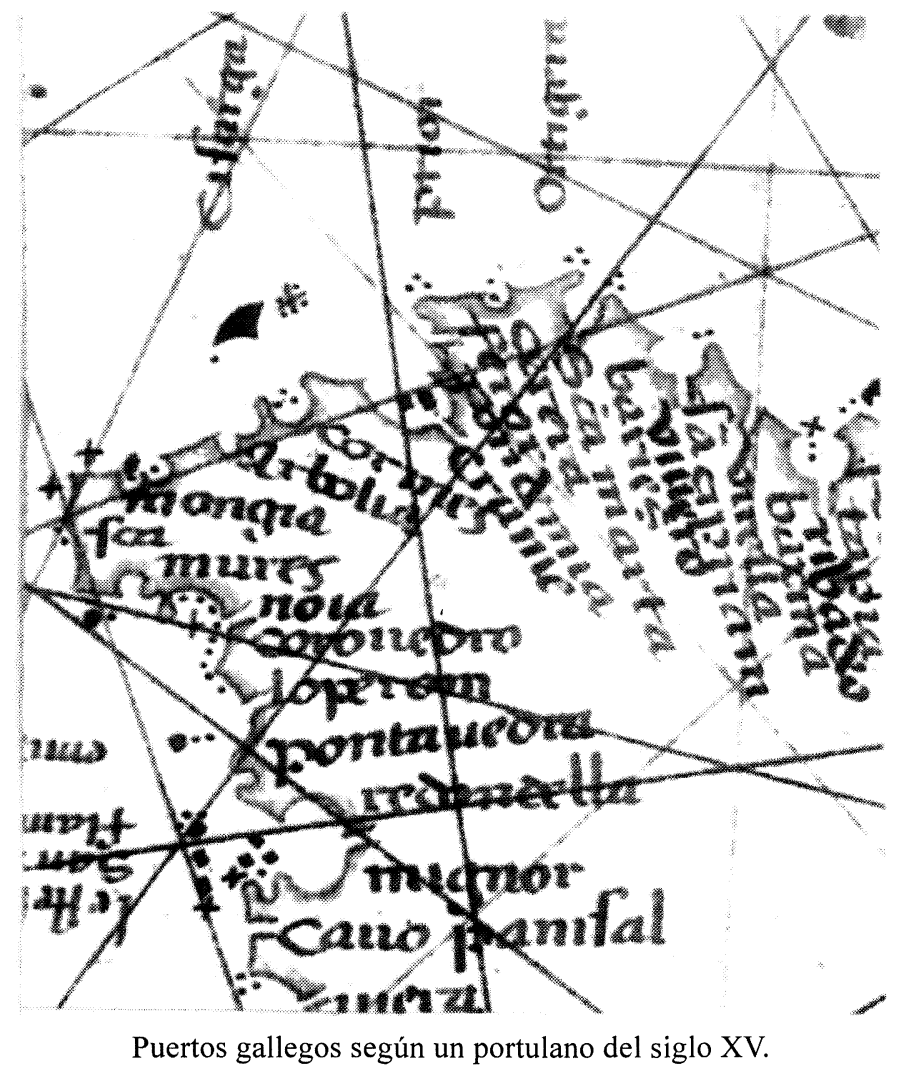

Redondela. En este caso el período de pago era semestral y no anual, ya que se hacía por dos terminos, Uno por natal e outro por San Juan Bautista. Es decir, en Diciembre y en Junio.

$\mathrm{Al}$ igual que el resto de los sectores sociales, los clérigos también tenían que pagar el diezmo, el derecho eclesiástico obligaba a los clérigos beneficiados a pagar el diezmo por la renta de su beneficio, fuera «curado» o «sinecura», al propio obispo. Tampoco estaban exentos los nobles, príncipes y reyes. Los judíos e infieles tenían que pagar los diezmos prediales cuando adquirían tierras que previamente se diezmaban, pero no estaban obligados a satisfacer los diezmos personales ${ }^{13}$.

${ }^{13}$ BARREIRO SOMOZA (Gran Enciclopedia Gallega, T. IX), op. cit., pág. 110.

"CUADERNOS DE ESTUDIOS GALLEGOS", Tomo XLVII, Fascículo 113, Santiago 2000. 
La sentencia del obispo Don Pedro Beltrán eximía a los parroquianos de las villas de Vigo y Redondela del pago de los referidos paños y camas a los rectores de las iglesias de Santa María de Vigo, Santiago de Redondela y Santa María de Reboreda, aunque no parece que esa exención afectase a los parroquianos que vivían en el área rural de esas feligresías.

Por la contra, los mareantes feligreses y parroquianos de las iglesias antes citadas, en conflicto con sus respectivos abades por el diezmo del pescado fresco, tendrían que pagar por éste en la proporción de una pieza por cada quince capturadas, cualquiera que fuera su especie, artes empleadas o lugar donde se hubiera pescado y/o desembarcado. Previamente, el pesoheiro de cada barco debía jurar anualmente en el día de San Juan y ante el altar de su iglesia que diezmaría de buena fe.

Del pescado que se desembarcaba en los puertos, una parte se vendía directamente para el consumo inmediato, pero otra parte se elaboraba para ser exportado o conservado para su consumo a más largo plazo. Este era el pescado que se salaba, ahumaba o secaba y del cual -según el documento- los mareantes pagaban el diezmo.

Sin embargo, el pescado fresco que se vendía y consumía en el día era mucho más difícil de controlar, al venderse o repartirse en el momento de la descarga. La dificultad aumentaba si la descarga se hacía en un puerto diferente al de origen. Razón por la cual, las autoridades eclesiásticas procuraron dejar muy clara la forma y manera en que debía pagarse el diezmo en estos casos.

El pescado del que se hace mención en el documento es variado: congrios, pescadas, polvos, sardinas, vesugos, sardas, burases, melcas, bodios, melloas, ollos moles, cabras, taiñas, lagostas..., al que se añade todo outro qualquer pescado viñer.

Las artes que se empleaban en las actividades pesqueras eran de red y liña, trasmallo y sacada. Las liñas y cordeles con anzuelos se emplearon en todo tiempo para la pesca de congrios, merluzas, cabras (escarapotes), pulpos y otras especies de fondo. Muchos pescadores, sobre todo tramalleiros y jeiteiros, llevaban consigo cordeles y liñas con las que, en los tiempos de espera, pescaban dichas especies ${ }^{14}$.

${ }^{14}$ FERREIRA PRIEGUE, E.: Galicia en el comercio marítimo medieval. Fundación Pedro Barrié de la Maza. A Coruña, 1988, págs. 141-142.

"CUADERNOS DE ESTUDIOS GALLEGOS", Tomo XLVII, Fascículo 113, Santiago 2000. 
La creciente demanda de pescado a finales del siglo XV y principios del XVI introdujo en algunas rías un aparejo más evolucionado: la cuerda o espinel, especie de palangre con muchos anzuelos, que se extendía en los fondos ${ }^{15}$. Los hespineles de picas, que ya habían sido conflictivos en 1501, se prohibieron en la ría de Vigo en 1573 y en la de Pontevedra en $1577^{16}$.

Los trasmallos (de tres mallos o mallas) eran redes fijas formadas por tres paños superpuestos: los dos exteriores iguales y el del medio de malla más pequeña. Se utilizaban para trabajar en aguas costeras pudiéndose lanzar desde un bote o desde tierra. Era un arte tradicional, conocido en toda Europa, y el favorito de los pescadores modestos, ya que necesitaba poca gente -tres o cuatro hombres para largar y recoger- y ni siquiera exigía la propiedad del bote. Se pescaban con él langostas y los peces sin valor en el comercio a larga distancia: los «peces de roca», que se vendían frescos en el mercado, como budiones, barbos, robalizas, fanecas, maragotas, pintas, bogas, etc, y algunos otros de más categoría como los besugos, entonces no lejos de la costa ${ }^{17}$. El trasmallo era la principal de las llamadas «artes fijas menores».

La sacada correspondía a un tipo de arte más evolucionada o «mayor». Se utilizaba sobre todo para la pesca de la sardina. Consistía en una red barredera compuesta por varias piezas unidas que le daban una forma rectangular. Sus extremos más largos eran convexos, de forma que, al cobrarla, formaba en el centro una especie de bolsa en la que quedaban atrapadas las sardinas y que -una vez cerrada- formaba un corral o «parque» del que se iba sacando el pescado con calma a lo largo de varios días ${ }^{18}$. La red se arrastraba con dornas y pinazas (embarcaciones pequeñas y ligeras) y también desde tierra, a fuerza de brazos o tirando de ella con animales.

\footnotetext{
${ }^{15}$ Ibidem.

${ }^{16}$ Ibidem. Para la Ría de Vigo véase SAMPEDRO Y FOLGAR, Casto: «Ordenanzas de pesca para la Ría de Vigo, Redondela y Cangas». Museo de Pontevedra. Tomo X (1956), págs 171-176.

${ }^{17}$ FERREIRA PRIEGUE, págs. 139-140.

${ }^{18}$ ARMAS CASTRO, J.: Pontevedra en los siglos XII a XV. Configuración y desarrollo de una villa marinera en la Galicia medieval. Fundación Pedro Barrié de la Maza. Pontevedra, 1992, pág. 144. También en FERREIRA PRIEGUE, pág. 140.
}

"CUADERNOS DE ESTUDIOS GALLEGOS", Tomo XLVII, Fascículo 113, Santiago 2000. 
Había dos tipos de sacada: la alta (do alto, en el documento) y la baja (do baixo), que se empleaban respectivamente en invierno y en verano. La primera duraba, probablemente, desde Enero hasta San Juan (Junio) y la segunda el resto del año ${ }^{19}$. En las rías de Vigo, Redondela y Cangas, las Ordenanzas del siglo XVI solo autorizaban las sacadas bajas, debido a la competencia que estas representaban para los $\operatorname{cercos}^{20}$, que eran el sistema más importante de pesca en ese momento y al que seguían en el número de capturas que proporcionaba.

La sacada era una técnica muy eficaz (y sus piezas muy caras, al parecer) en la captura de la sardina, movilizando a gran cantidad de gente en la época de mayor actividad ${ }^{21}$.

El documento no nombra artes tan importantes como el cerco y el jeito que ya se utilizaban en la ría y están perfectamente documentadas para los siglos XV y XVI. Quizá el úso del cerco había sido menos frecuente hasta el momento debido al despliegue material y humano que requería. De todas formas, las cláusulas de la Sentencia preveían el pago del diezmo del pescado en qualquer maneira que pase do mar en terra.

El cerco, más o menos contemporáneo del jeito, estaba formado por un grupo numeroso de personas cuya participación se realizaba mediante «quiñones», constituidos por barcos, redes y trabajo -elementos materiales del aparejo-, repartiéndose los beneficios obtenidos de manera proporcional a cada aportación.

Constaba de una gran red (compuesta de muchos «quiñones») y un barco mayor -el trincado-, para el transporte y tendido de la red, que se iba haciendo con la ayuda de un bote auxiliar, formando así un «corral» que luego se arrastraba a tierra. Cuando se hacían a la mar, los atalieiros (armadores de los cercos) oteaban la ría desde la proa de los barcos, dando la voz de alarma cuando descubrían un banco de sardinas, lo cual suponía su posesión y el que ningún otro cerco pudiera acercarse ${ }^{22}$. Este sistema era el que proporcionaba las capturas más numerosas, por lo que era el preferido de los mareantes en esta época.

\footnotetext{
${ }^{19}$ Ibidem.

${ }^{20}$ SAMPEDRO Y FOLGAR, «Ordenanzas...», op. cit.

${ }^{21}$ ARMAS CASTRO, op. cit., pág. 144 y FERREIRA PRIEGUE, op. cit., págs. 140-141.

${ }^{22}$ Ibidem, págs. 143 y 141 respectivamente.
} 


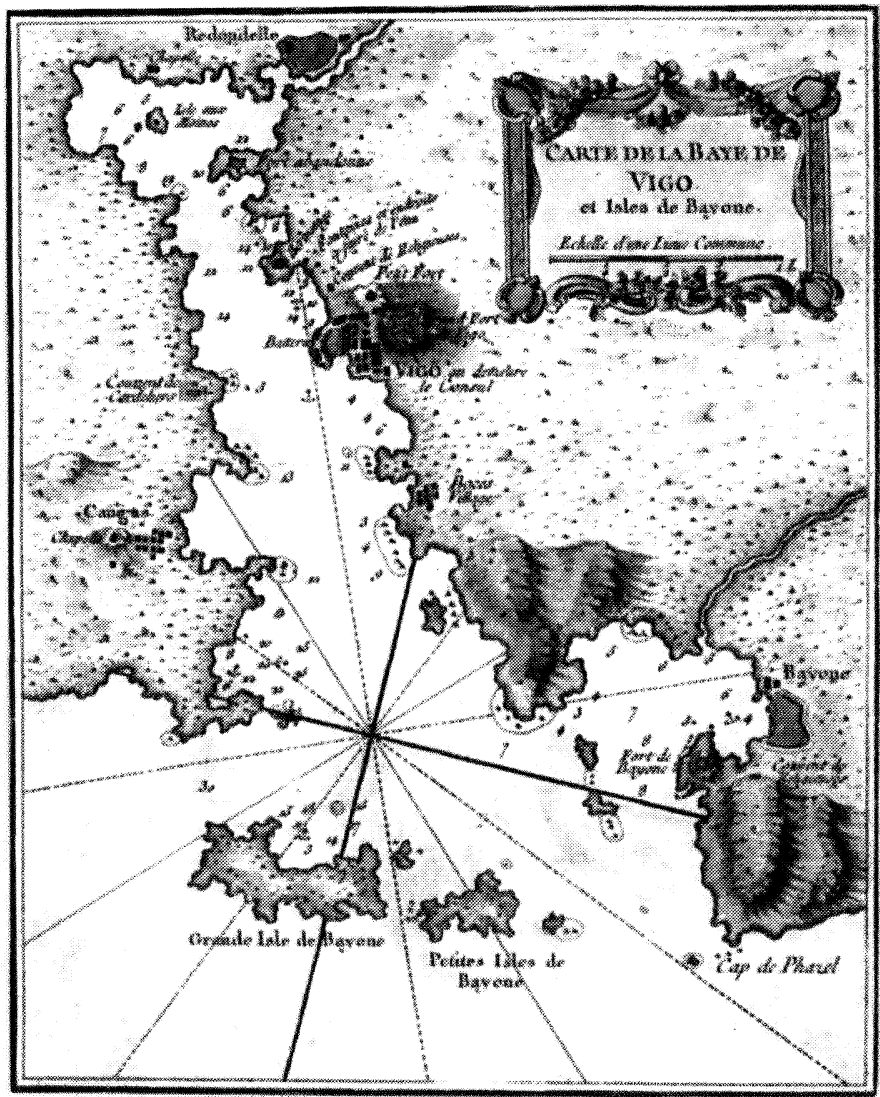

Carta náutica de la Ría de Vigo. Siglo XVIII.

Se detallan las villas de Redondela, Vigo y Bayona.

El jeito, arte de deriva, era el más frecuente y antiguo entre los pequeños pescadores y aquellos mareantes que no entraban en los cercos. Su aparejo consistía en una red formada por varias piezas unidas que se lanzaba desde un bote, manteniéndose a flote y creando una barrera contra la que tropezaban las manadas de sardinas, que quedaban enganchadas por las agallas o la cabeza, evitando que la carne se «mazara». Al recuperar la red las sardinas se desenganchaban a mano, una a una, constituyendo una variedad muy apreciada ${ }^{23}$.

${ }^{23}$ Ibidem, págs. 144-145 y 140 respectivamente.

"CUADERNOS DE ESTUDIOS GALLEGOS", Tomo XLVII, Fascículo 113, Santiago 2000. 


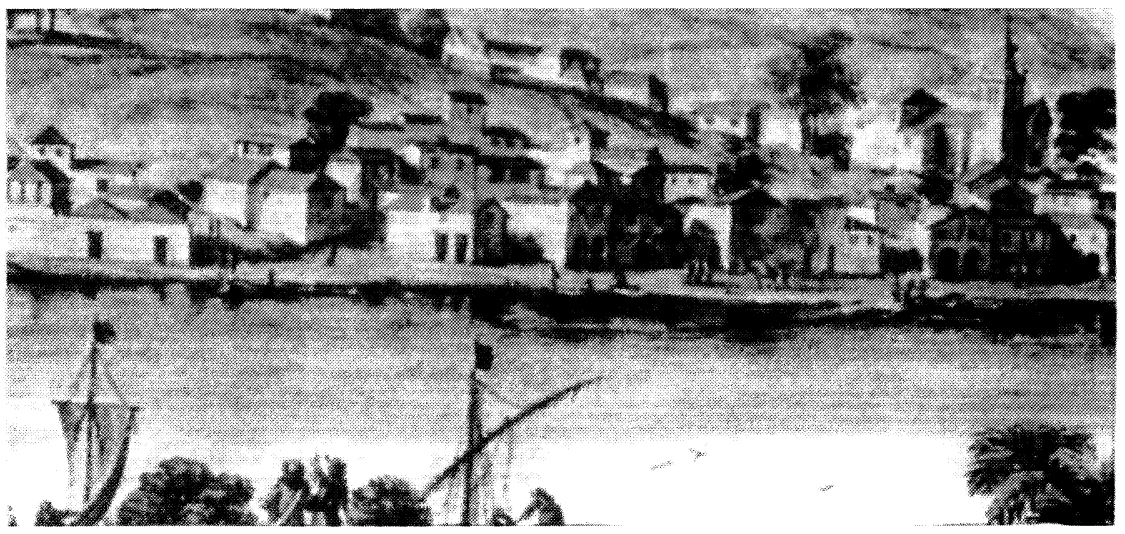

A Riveira de Redondela en el siglo XVII.

Era un procedimiento muy eficaz y flexible, aunque no tan rentable como la sacada y el cerco, las grandes artes barrederas. En cualquier caso, el jeito representaba también una competencia para los cercos, cuyos mareantes lo consideraban una técnica muy dañosa que llegaron a prohibir durante la época en que estos faenaban ${ }^{24}$.

La villa de Redondela desarrollaba actividades pesqueras cuando menos desde el siglo XIII ${ }^{25}$. Los redondelanos estaban además, al parecer, en posesión de pescar con sus cercos en la ría desde las Islas de las Hervederas (Erbedosas) hasta las Cíes ${ }^{26}$, y debían guardar las normas que, en cuestiones de pesca (sobre calendarios y artes), dictaban los vicarios de la cofradía de mareantes do Corpo Santo de Pontevedra ${ }^{27}$.

\footnotetext{
${ }^{24}$ SAMPEDRO Y FOLGAR, «Ordenanzas...», op. cit.

${ }^{25}$ En esa época el monasterio de Melón recibía y centralizaba allí parte de sus rentas en pescado, sobre todo sardinas, merluzas y besugos, con que se pagaban las heredades aforadas. (PORTELA SILVA, E.: La Región del Obispado de Tuy en los siglos XII a XV. El Eco Franciscano. Santiago, 1976, págs. 183-184). En el siglo XV continuaban haciéndose estos pagos, tanto en pescado fresco como salado. (SÁNCHEZ CARRERA, op. cit., págs. 63-64).

${ }^{26}$ «Los vecinos de Redondela con Juan Domínguez y otros (de Cangas), sobre pesca de Sardina». A.R.G. Pleito rotulado «Piillado», s. XVI. Letra L. ${ }^{\circ}{ }^{\circ}$. Resumen del mismo publicado por MARTÍNEZ SALAZAR, A. «Litigios entre los mareantes de las Rías Bajas sobre posesión del Mar. 1561-1678». El Museo de Pontevedra, Vol. III (1945), pág. 73.

${ }^{27}$ Ordenanzas de Mareantes de 1523. (Museo de Pontevedra. Archivo de Mareantes, I, 7b, fol. 3).
}

"CUADERNOS DE ESTUDIOS GALLEGOS", Tomo XLVII, Fascículo 113, Santiago 2000. 
Dividida en dos jurisdicciones: la Vilavella y la Vilanova de Redondela, la primera pasó a depender del Obispo e Iglesia de Tuy en 1371, por donación del Rey D. Enrique II, luego de haber pertenecido sucesivamente al señorío de la Orden del Temple (hasta 1312), al realengo, y al caballero petrista D. Suero Yañez de Parada ${ }^{28}$. La segunda, la Vilanova -renovación debida, quizás, al rey $\mathrm{D}$. Alfonso $\mathrm{X}$, de quien pudo recibir fuero o Carta de Población ${ }^{29}$-, fue cedida al señorío de los Arzobispos Compostelanos, posiblemente a mediados del siglo XIII ${ }^{30}$, y se hallaba rodeada de una cerca o muro al menos desde el primer tercio del s. XIV ${ }^{31}$.

En 1304, el rey Don Fernando IV concedió al Arzobispo de Santiago la mitad de las décimas o diezmos de la mar (un impuesto indirecto sobre el tráfico de mercancías que entraban o salían por los puertos) que le correspondían del puerto de Redondela y otros de la Iglesia Compostelana ${ }^{32}$.

${ }^{28}$ Tras la disolución de la Orden del Temple, sus antiguos señores, en 1312, la Vilavella de Redondela pasó al realengo, siendo cedida más tarde al Caballero D. Suero Yañez de Parada. El Rey D. Enrique II confiscó la Villa y todos los señoríos y heredades de este caballero, distinguido por su apoyo al Rey D. Pedro I «el cruel» en la contienda por el trono que ambos hermanastros mantuvieron, donándosela al Obispo e Iglesia tudense en 1371.

(Documento de donación en GALINDO ROMEO, Pascual: Tuy en la Baja Edad Media. Siglos XII-XV. Instituto «Enrique Flórez». C.S.I.C. Zaragoza-Madrid, 1923. Doc. XXIV, págs. XXVI-XXVII).

Según un foro de 1498, la Vilavella de Redondela pertenecía al Obispo y al Cabildo por mitad. (A.C.T., Pergaminos 13/34. Cit. por SÁNCHEZ CARRERA, op. cit., pág. 213).

${ }^{29}$ Véase RUIZ DE LA PEÑA SOLAR, J.I.: «El desarrollo urbano de la periferia norteña Castellano - Leonesa en la Edad Media (siglos XII- XIV)». Anuario de Estudios Medievales, $n^{\circ} 19$ (1989), pág. 177.

${ }^{30}$ No hemos encontrado, por el momento, ninguna prueba documental al respecto. Sin embargo, la existencia en este siglo de propiedades de la Mitra en el área de Redondela, donde ya aparecen pertigueros (jueces especiales del señorío arzobispal) en los años $1258-60$, y el hallarse expresada como villa o puerto del arzobispo en los primeros años del siglo XIV (docs. de los años 1304, 1308, 1310 ...), nos hacen suponer tal hipótesis.

${ }^{31}$ En 1333, Juan Perez, Carpintero de Redondela, vende aquella casa que esta asentada ena rua do valle... e en fondo vay entestar ao muro da cerca da dita villa. (A.H.N., Clero Melón, carp. 1462, núm. 8. Citado por PORTELA SILVA, E.: La región del Obispado de Tuy..., op. cit. pág. 94).

${ }^{32}$ 1304/05/07. Fernando IV otorga al arzobispo don Fray Rodrigo y a sus sucesores la mitad de las diezmas que el monarca tenía en todos los puertos de la tierra de Santiago. (A.C.S., Tumbo B, fol. 75 v.-77r.). A esto se añadieron en 1310 otros 10.000 maravedíes donados al arzobispo don Rodrigo y a sus sucesores sobre la mitad de las diezmas correspondientes a la corona. Entre estos puertos se menciona expresamente al de Redondela

"CUADERNOS DE ESTUDIOS GALLEGOS", Tomo XLVII, Fascículo 113, Santiago 2000. 
En Febrero de 1467, D. Enrique IV confirmó los Privilegios anteriores concedidos a los arzobispos para el cobro en la población de diversas rentas y servicios, como los cambos (nombre, al parecer, de una medida para el pescado, el cambo), que en 1592, tras pleitos y discusiones sobre su pago, el juez arzobispal de Redondela estableció en un millar de sardinas por barco y la mitad por dorna desde Noviembre hasta Enero ${ }^{33}$.

Desde antes de 1438 la villa disponía de un alfolí (estanco o almacén autorizado) de la sal ${ }^{34}$, que necesitaba para la conservación del pescado, especialmente sardinas, de cuyas importantes capturas exportaba parte al Mediterráneo junto con algunos otros productos, a través de una pequeña flota $^{35}$.

Como antiguo puerto de marea, presente en casi todos los mapas portulanos desde el siglo XIV, comenzaba a sufrir los efectos del progresivo levantamiento de la $\operatorname{costa}^{36} \mathrm{y}$-sobre todo-de su encenagamiento, debido al lento pero inexorable proceso de sedimentación de los depósitos aluviales, arrastrados por los dos pequeños ríos que confluían en el apéndice

(1310/02/20. A.C.S.,Tumbo B, fol. $310 \mathrm{r}$ - $311 \mathrm{v}$.). Ambos documentos transcritos por GONZÁLEZ BALASCH, M.T.: El Tumbo B de la Catedral de Santiago. Edición y Estudio. Granada,1978, tesis doctoral inédita.

Las diezmas o diezmos de la mar consistían en un gravamen sobre la importación y exportación de productos a través de los puertos marítimos y no deben confundirse con los diezmos del pescado, a veces también llamados de la mar.

${ }^{33} \mathrm{Si}$ durante ese tiempo no pescasen sardina o se dedicaran a otra especie deberían pagar cuatro reales por Barco y dos por Dorna. Además, habían de pagar por cada carga de sardina que se exportase por tierra un maravedí, y siendo pescado seco o fresco dos mrs. y medio, y cada Barco un real. No obstante, los pleitos continuarían en el siglo XVII. (VÁZQUEZ LIJO, J. M.: «Aproximación a la fiscalidad sobre la pesca en el Barbanza del Antiguo Régimen. El Diezmo de Mar y otras cargas». Cuadernos de Estudios Gallegos. Tomo XLVI, Fascículo 111, Santiago, 1999, pág. 89 (Apéndice Documental), y GARCÍA BRAÑA, JUEGA PUIG, DE LA PEÑA SANTOS: Pontevedra, Planteamiento Histórico y Urbanístico. Diputación de Pontevedra, Vigo, 1988, pág. 126).

${ }^{34}$ 1438/11/20. Pedro Cruu y Gonçalvo de Camoens arriendan los alfolíes de Pontevedra, Vigo, Redondela y sus Rías por un período de 5 años. (Museo de Pontevedra, col. Sampedro, caja $4 / 6$, fol. 2 v.). El alfolí de Redondela proveía, en los años 50 del siglo $\mathrm{XV}$, incluso a los arrieros de A Limia y Ourense cuando estos tenían dificultades para abastecerse en Valença do Minho. (BAQUERO MORENO, H.: «Relaçôes entre Portugal e Galiza nos séculos XIV e XV», en Revista da Facultade de Letras. Historia, vol. 7. Porto, 1990, pág. 40).

${ }^{35}$ FERREIRA PRIEGUE, pág. 100. La sal era necesaria también para conservar los cueros, que se exportaban sin curtir. (Ibidem, 156-157).

${ }^{36}$ Ibidem, pág. 95.

"CUADERNOS DE ESTUDIOS GALLEGOS", Tomo XLVII, Fascículo 113, Santiago 2000. 
o brazo de mar (hoy prácticamente desaparecido) al que se asomaba la villa y que, junto con la ensenada del Ulló o de San Simón (la concha que se dibuja desde el estrecho de Rande hacia el interior de la ría y su prolongación), formaba la ría de Redondela.

Este fenómeno, al que se añadía la acumulación del lastre arrojado por los barcos, se vio agravado a lo largo del siglo XVI, a pesar de que se intentaron algunas medidas para paliar sus efectos, tratando de construir un muelle seguro y de mantener limpio y desembozado el puerto ${ }^{37}$. El problema se vería acentuado desde el último tercio de ese siglo y en la siguiente centuria a causa de la deforestación de los montes circundantes, sumada a los efectos de un período de enfriamiento y de lluvias intensas ${ }^{38}$ que acelerarían el proceso de erosión y sedimentación.

Probablemente, estas circunstançias unidas a la realización de faenas pesqueras en algunos caladeros situados cerca de los otros puertos de la ría, con más profundidad y mejor acceso para las embarcaciones mayores, y en los que también había una gran demanda y una rápida venta del pescado fresco para su posterior elaborado y exportación, motivarían seguramente que, en ocasiones ( las devegadas), las cuantiosas capturas de los mareantes redondelanos ${ }^{39}$ pasaran a engrosar el volumen de la pesca que se desembarcaba en los puertos de Cangas, Bayona, Vigo, e en outras partes.

${ }^{37}$ GARCÍA ORO, J. y PORTELA SILVA, M.J.: Bayona y el espacio urbano tudense en el siglo XVI. Estudio Histórico y Colección Diplomática. Santiago de Compostela, 1995, pág. 208 y también doc. pág. 380.

${ }^{38}$ Pontevedra, Planteamiento Histórico y Urbanistico, op. cit. págs. 56-57.

${ }^{39}$ En el mismo año en que se promulga la sentencia (1494), un viajero alemán de paso por Redondela anotaba en la relación de su viaje que la villa est sita super uno brachio maris, ubi sardinas in mirabili copia piscantur. (Jerónimo Muenzer: "Itinerarium Hispánicum Hieronymi Monetarii», publicado por VÁZQUEZ DE PARGA, LACARRA y URIA RIU: Las peregrinaciones a Santiago de Compostela. C.S.I.C., Madrid, 1949, T. III, pág. 133).

En 1550 el Licenciado Molina escribía que Luego adelante esta una buena ria donde estan las villas de bigo y redondela que son de gran pesca de sardina y pescada: y adelante esta cangas: do se toma abundancia de congrio: $y$ destos tres pueblos se provee por tierra mucha parte deste reyno y aun de castilla de todos pescados... (MOLINA, Bartolomé Sagrario de: Descripción del Reyno de Galizia. Mondoñedo, 1550, fol. XXV).

Aún en 1774 la flota redondelana tenía unas capturas estimadas en 30.000 millares de sardinas, lo que situaba al puerto de Redondela en los primeros puestos entre los que se extendían desde A Guarda hasta Noya, solo superado por los de Cangas y Vigo, éstos en su misma ría. (Véase CORNIDE, José: Memoria sobre la pesca de la sardina en las costas de Galicia. Madrid, 1774).

"CUADERNOS DE ESTUDIOS GALLEGOS", Tomo XLVII, Fascículo 113, Santiago 2000. 
Las actividades pesqueras de Redondela se concentraban a lo largo de la rua da Riveira, extramuros de la villa. Allí se realizaba la descarga y venta del pescado y se verificaba el pago del diezmo. También era el lugar adonde se trasladaría más tarde el alfolí de la $\mathrm{sa}^{40}$, y donde seguramente se llevaban a cabo otras actividades comerciales y fiscales. En un extremo de la Riveira hacia la ría, y como prolongación del puerto, se hallaba el cabo dos Fumeiros, en clara alusión a las casetas donde se ahumaban las sardi$\operatorname{nas}^{41}$. Hacia el lado contrario, en un espacio inmediato que comunicaba con el interior y la parte alta de la villa, se encontraba el estaleiro (astillero) ${ }^{42}$

\footnotetext{
${ }^{40}$ Parece que hasta el siglo XVIII la Casa vieja Alfolí estuvo ubicada en la Rua do Ribeiro, intramuros de la villa y cerca de la Ribeira, construyéndose en su lugar la Casa Consistorial en 1788 (A.H.D.PO. «Expediente construcción Ayuntamiento». Leg. 1911), pero ya bastante antes de esta última fecha se encontraba en la dicha rua da Riveira (donde también se hallaba la Praza do peixe), y aún hasta mediados del s. XX los depósitos de la sal estaban situados en esa misma calle, concretamente donde hoy es el edificio llamado de Pedales.

${ }^{41}$ El Fumeiro era una caseta sin chimenea que dejaba entrar por los intersticios del tejado el oxígeno indispensable para la combustión, allí se colocaban las sardinas ensartadas por las agallas en unas cañas, después de recibir un baño de salmuera y un ligero prensado. El fuego se hacía con ramas verdes de laurel, roble, pino, hiedra y cualquier otra leña que despidiese mucho humo y las aromatizase. El proceso podía durar una o dos semanas; el momento de retirarlas del fuego era a discreción de la persona que las vigilaba y era fundamental para su calidad. Las sardinas ahumadas o arencadas, correctamente envasadas, podían durar hasta un año o año y medio sin peligro de estropearse. (FERREIRA PRIEGUE, op. cit. págs. 146-147).

Hacia 1671 había un peirao en el Cabo (o los Cabos) dos Fumeiros, extramuros de la Villa, entre otros varios de su espacio costero urbano (M. P. Col. Sampedro, C.91.9).

El Cabo dos Fumeiros desapareció hace años de la toponimia de Redondela debido a los sucesivos rellenos que han cubierto la zona de la ría a la que se asomaba la villa, incluyendo este pequeño cabo, hoy una curva, punto de unión entre las calles Xeneral Rubín y Santa Mariña.

42 1520. La Justicia y Regimiento de Redondela y los Mayordomos del hospital de pobres de la misma villa aforan a Pedro da Boza un fumero en el estalero de la ribera. (A.H.P.PO. Hospital de Redondela. Leg. 2168. Núm.. 12).

En 1531, Juan Peres, marinero de Matosinhos, vende a Sebastian de León, mercader de Pontevedra, la tercera parte del navío San Antonio, que se está construyendo en Redondela. (A.H.P.PO. Protocolos. Leg. 829 (2), fol. 119 v.).

Este espacio pasó a llamarse sucesivamente praza do Estaleiro o Asteleiro, do mercado y, más tarde, praza da Constitución. (Sobre toponimia y calles redondelanas véase SOTO LÓPEZ, A.: «Toponimia urbana de Redondela». Boletín del Seminario de Estudios Fontan-Sarmiento. Año 3, núm. 1 (Oct-Dic., 1980), págs. 8-11).
}

"CUADERNOS DE ESTUDIOS GALLEGOS", Tomo XLVII, Fascículo 113, Santiago 2000. 
-hoy convertido en una plaza-, y no muy lejos de allí el Campo das redes ${ }^{43}$, donde se extendían las mallas para su reparación.

Redondela aún mantendría mucho tiempo su importancia pesquera, basada -en gran medida- en la pesca de sardina y el escabeche de la os$\operatorname{tra}^{44} \mathrm{y}$, más tarde, a través de una importante flota de bajura, hoy con base en la parroquia de Cesantes ${ }^{45}$; participando también del tráfico comercial que propiciaba su situación en el eje viario que comunicaba Galicia de Norte a Sur y con el Norte de Portugal. Sin embargo, los problemas antes aludidos de su fondeadero, la cercanía del poderoso puerto de Pontevedra y posteriormente el desarrollo del magnífico puerto vigués, todo ello unido a los sucesivos saqueos y destrucciones a los que se vio sometida ${ }^{46}$, condicionarían en gran parte su desenvolvimiento y evolución.

${ }^{43}$ 1510. Juan Milleiro y Gonzalo de Lantaño, mayordomos del hospital de pobres de Redondela, aforan una heredad situada en el Campo das redes. A.H.P.PO. Hospital de Redondela. Leg. 2168. Núm. 12)

${ }^{44}$ Sardina y ostra son el mantenimiento prinçipal de la dicha villa. (A.G.S., R.G.S. IX-1605. «Ordenanzas hechas por las villas de Redondela y Villavieja». Citadas por GARCÍA ORO, J. y PORTELA SILVA, M.J.: Bayona y el espacio urbano tudense..., op. cit. pág. 207).

En Redondela existía un Gremio de Toneleros (Cofradía de S. Sebastián), compuesto por carpinteros especializados en la fabricación de unos barriles adecuados para el escabeche de la ostra. (Véase M. P. Col. Sampedro, C. 91.21, y LÓPEZ CAPONT: «Austrias y Borbones consumían ostras gallegas en escabeche...» La Voz de Galicia, 13-oct.-1991). También había banasteros, cuyas cestas o banastas servían para la exportación del pescado.

${ }^{45}$ La pesca en Redondela sigue siendo importante, y su puerto, hoy ubicado en Cesantes, es uno de los diez primeros dentro de la clasificación gallega, con una flota esencialmente de bajura caracterizada por la captura de pescado de baja cotización como la sardina y el jurel, siendo también muy relevante el marisqueo de moluscos bivalvos, especialmente en la Ensenada de San Simón. (Véase PAZO LABRADOR, Alberto: «As Rías Baixas Pontevedresas e o seu pospaís: Xeografía Humana e Económica» en Galicia-Xeografia, Tomo XIX. Hércules de Ediciones, A Coruña, 1996; pág. 345). Hoy en día, gran parte de las descargas del pescado suelen hacerse en el puerto de Vigo.

${ }^{46}$ Aparte de los efectos causados por la guerra con Portugal en la $2^{\mathrm{a}}$ mitad del siglo XVII, Redondela fue ocupada por los anglo-holandeses durante los días posteriores a la batalla naval de Rande en 1702, siendo saqueada a conciencia en tres ocasiones (dos de ellas por españoles). En 1719 fue de nuevo ocupada por los ingleses, quienes la saquearon e incendiaron; pero el momento más grave fue en 1809, cuando tropas francesas, furiosas por haber sido hostigadas por la guerrilla, atacaron inesperadamente la villa, diezmando violenta e indiscriminadamente a sus indefensos habitantes y pegando fuego a sus edificios, perdiéndose también los libros y papeles de Redondela.

"CUADERNOS DE ESTUDIOS GALLEGOS", Tomo XLVII, Fascículo 113, Santiago 2000. 


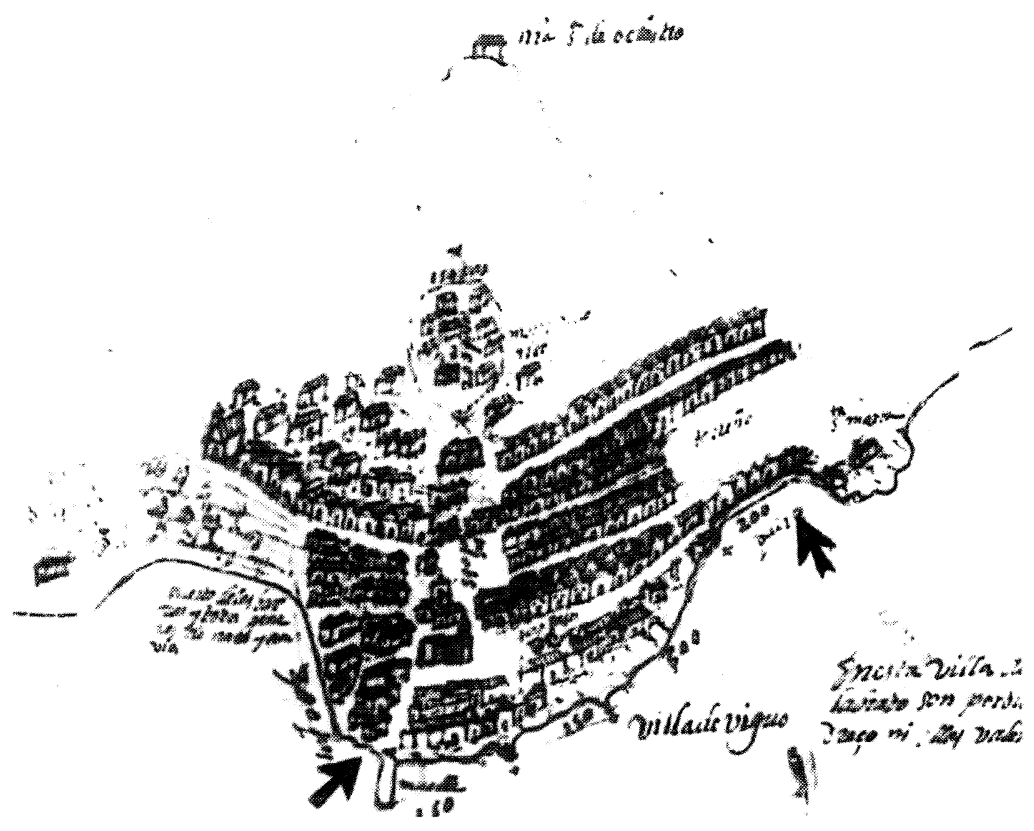

La villa de Vigo y su puerto en 1597. (Archivo General de Simancas).

(Las flechas señalan las zonas de $A$ Ladeira y O Berbés).

Por su parte, la villa de Vigo se había ido conformando como tal desde principios del siglo XV. Hasta entonces su población se había ido agrupando lentamente alrededor de varias feligresías, muy especialmente en torno a las de Santa María de Vigo y Santiago de Vigo en la Terra de Fragoso, que pertenecían al Cabildo y Obispo de Tuy.

Sobre este territorio, los monarcas Alfonso VII y Fernando II realizaron una serie de concesiones al monasterio cisterciense de Santa María de Melón que, añadidas a la donación de la heredad de Condomiñas (o de Vigo) realizada por la condesa doña Fruila Fernandez, culminarían con la concesión al cenobio, en octubre de 1176, del regalengum de Vigo con todos sus derechos y jurisdicciones in litore maris ${ }^{47}$.

${ }^{47}$ A.H.N. Sección Clero. Libro de los privilegios del Monasterio de Melón. Tomo III, fol. 454. Copia simple del siglo XIX. Transcribe y publica este documento y menciona las distintas donaciones SANTIAGO Y GÓMEZ, José de: Historia de Vigo y su comarca. Madrid, Imp. Asilo de Huérfanos, 1896, págs. 161-164 y 196-201.

"CUADERNOS DE ESTUDIOS GALLEGOS", Tomo XLVII, Fascículo 113, Santiago 2000. 
Este espacio, que andando el tiempo se llamaría o Berbés, era al principio una playa sin infraestructura portuaria, donde se realizarían las primeras actividades pesqueras, limitadas a la pesca de bajura practicada por sus habitantes marineros-campesinos como complemento de la dieta alimenticia y para el pago de sus obligaciones señoriales como foreros, dentro de un ámbito todavía rural ${ }^{48}$.

En el siglo XIII (1234), probablemente basándose en privilegios más antiguos, el Arzobispo de Santiago Don Laurencio disputó y obtuvo el señorío jurisdicional sobre el lugar frente a los abades de Melón, pasando Vigo a depender de la Mitra compostelana pero salvando los derechos del monasterio sobre sus cotos, granjas y heredades ${ }^{49}$.

A principios del siglo XIV, el puerto de Vigo se encontraba entre aquellos de cuyas diezmas de la mar había cedido el rey Fernando IV la mitad al Arzobispo de Santiago ${ }^{50}$, aunque sus actividades portuarias, y por ende tales diezmas, se producían con un carácter esporádico y con cierta dependencia respecto del puerto de Redondela ${ }^{51}$, y sin que tampoco hubiese llegado a consolidarse un verdadero núcleo urbano.

${ }^{48}$ BRAGADO RODRÍGUEZ, E. y SÁNCHEZ BARGIELA, R.: O Vigo das Igrexas Románicas. Concellería de Patrimonio Histórico e Medio Ambiente. Concello de Vigo, 1993, pág. 27.

${ }^{49}$ Véase lo que escribe al respecto SÁ BRAVO, Hipólito de: El Monacato en Galicia. Ed. Librigal. A Coruña, 1972, Tomo II, págs. 269-271.

${ }^{50}$ Véase supra nota 32.

${ }^{51}$ Estos son los moravedis quel arçobispo ha en Redondela e eso mismo los derechos que ha: primeyramente: la meytad de los diesmos del porto de Redondela e de Vigo, quando se faze. (A.H.D.S. Libro Registro de Bienes y Rentas de la Mitra, fol. 31. Esta parte del códice, hasta el fol. $59 \mathrm{v}^{\circ}$, fue redactado seguramente entre 1398 y 1405, aunque recoge testimonios anteriores).

En 1450 se registra una comanda para Vigo hecha desde Barcelona (unos cuantos paños y chales), a través de un mercader y navío de Redondela, que acaba cancelándose. (FERREIRA PRIEGUE, op. cit. pág. 101).

Esta autora, basándose en el fragmento citado (Libro Reg., fol. 31), afirma en su magnífico estudio que el puerto de Vigo estaba en esa época más o menos subordinado al de Redondela (pág. 136). Sin embargo, atribuye a este texto el año de 1435 , fecha de la compilación del códice, compuesto por tres partes de distinta cronología. Igual año apunta cuando se refiere (págs. 100, 382, 398...) a lo que se dice sobre los puertos de la diocesi de Santiago (fol. $66 \mathrm{v}^{\circ}$, en el que también se mencionan las medias diezmas del Rey en Vigo), que corresponde a la parte escrita entre los años 1331-1338, donde se incluyen documentos de fecha más antigua (fol. $74,74 \mathrm{v}^{\circ}$, regengo de Çedeira, 1322). Véase el 
Según Méndez Silva, la villa fue poblada hacia 1440, en época de Juan $\mathrm{II}^{52}$, quizá para compensar el efecto de las epidemias de peste ${ }^{53}$. Es posible que ello significara una carta de poblamiento que diese un nuevo impulso al tímido crecimiento de su puerto, que en esas fechas ya contaba con alfolís ${ }^{54}$.

Con todo, hasta el último tercio del siglo XV se hallaba con poca población, comenzando a crecer entonces más rápidamente ${ }^{55} \mathrm{y}$ continuando esta tendencia en el siglo XVI. En ese momento, la zona del Berbés seguía siendo propiedad del Cabildo de Tuy y del Monasterio de Melón, ambas instituciones concedían allí foros y tenían explotaciones agrícolas. Al primero pertenecía la llamada heredad e veiga que se chama do Ber$d e z^{56}, \mathrm{y}$ al segundo lo que estaba hacia la Ribera ${ }^{57}$, aunque el señorío de la villa seguía ejerciéndolo el Arzobispo compostelano.

análisis y las interesantes conclusiones respecto a esta fuente y su cronología en GONZÁLEZ VÁZQUEZ, Marta: El Arzobispo de Santiago: Una instancia de poder en la Edad Media (1150-1400). Seminario de Estudos Galegos. Ediciós do Castro. Sada, 1996, págs. $14-16$.

(El «Libro Registro de Bienes y Rentas de la Mitra» ha sido ya transcrito y editado, gracias al excelente trabajo de Don Ángel Rodríguez González, con el título de «O Tumbo vermello de Don Lope de Mendoza». Cuadernos de Estudios Gallegos. Anexo XXIII. Santiago, 1995).

52 [Vigo] ...Fue poblada años 1440. Reynando en Castilla Don Juan Segundo, sin más noticia. (MÉNDEZ SILVA, Rodrigo: Población general de España: sus trofeos, blasones y conquistas heroycas, descripciones agradables, grandezas notables... Madrid, 1645). El autor tomó los datos de relaciones manuscritas del Doctor Juan Salgado de Araúxo, nacido en Verín en el último tercio del siglo XVI.

${ }^{53}$ Así opina GONZÁLEZ MUÑOZ, M.C.: «Vigo y su comarca en los siglos XVI y XVII», en Vigo en su Historia. Caja de Ahorros Municipal de Vigo. Vigo, 1979, pág. 227.

${ }^{54}$ Véase supra nota 34.

55 ... en los tienpos passados que la poblaçon del lugar era deminuida e los freigueses eran en poco numero e la iglesia rendia poco, e que agora, procurandolo Ihesu Christo, la dicha villa se avia mucho poblado en muy grande numero de gente;... (Establecimiento y erección de la Colegiata de Vigo en el año 1497. Public. por FLÓREZ, Enrique: España Sagrada, theatro Geographico-Histórico de la Iglesia de España. Tomo XXIII (Iglesia de Tuy), Madrid, 1767, Apéndices, págs. 226-228. También en SYNODICON HISPANUM, op. cit. págs. 389-390).

SÁNCHEZ CARRERA (op. cit. págs. 186 y 193, etc.) constata también el escaso carácter urbano de Vigo durante casi todo el siglo XV.

${ }^{56}$ A.C.T. Libro 67. «Papeles y apeos de la tenencia de Santa María de Vigo y sus agregados», folio $2^{\circ}$. Citado por GONZÁLEZ MUÑOZ, M.C.: « Vigo y su comarca en los siglos XVI y XVII», op. cit., pág. 227.

${ }^{57}$ Ibidem, GONZÁLEZ MUÑOZ.

"CUADERNOS DE ESTUDIOS GALLEGOS", Tomo XLVII, Fascículo 113, Santiago 2000. 
Además de en el Berbés, en cuyas casas asignadas por los dizimeiros se pagaba el diezmo del pescado, los pescadores vigueses habitaban también en a Ladeira, la parte que iba desde la ladera del Castro hasta el mar. Allí estaban sus casas y allí se diezmaba igualmente el pescado que llegaba a su ribera (a riveira da Ladeira), que se correspondería con el espacio situado entre la Fuente de Vigo y La Piedra (hoy la zona de la avenida de Cánovas del Castillo a la altura de la estación marítima), no muy lejos del Berbés.

Según algunos autores, que se remiten a la tradición, el origen de este asentamiento pesquero, así como el del mismo Berbés (e incluso el de Bouzas), partiría de unos refugios construidos por los pescadores redondelanos cuando salían a faenar a lo largo de la ría ${ }^{58}$. Sea o no acertada esta hipótesis -que implica reconocer la antigüedad de las actividades pesqueras del puerto de Redondela-, tal conjetura refuerza la idea de que debió existir una estrecha relación entre los pescadores redondelanos y los del litoral vigués.

58 ...consta por tradición que las primeras casas de este pueblo consistían en unas pequeñas barracas, situadas en el sitio que llaman Ladeira (desde la Fuente de Vigo hasta la Piedra) construidas por los marineros de Redondela, en que se albergaban y pasaban algunas temporadas, cuando salían a la pesca, y por eso dicen se titulaba "Vigo de Redondela». (TABOADA Y LEAL, Nicolás: Descripción topográfico - Histórica de la Ciudad de Vigo, su ría y alrededores. Imprenta de la Viuda e Hijos de Compañel. Santiago, 1840, págs. 170-171. El subrayado es del autor).

... es un hecho evidente que en la época a que nos referimos [la E. Media] el puerto de Vigo, lejano ya el esplendor que sin duda alcanzó durante la época romana, se hallaba muy postergado, hasta el extremo de que apenas hacían uso de él los pescadores locales, así como los de Redondela, que tenian en Guixar y en el Arenal sus puntos de refugio... (MASSÓ, Gaspar: Pedro Madruga de Soutomayor caudillo feudal. Bibliófilos gallegos. Santiago de Compostela, 1975, págs. 197-198, nota 141).

... Para otros, el lugar [El Berbés] fue un refugio de los pescadores redondelanos que navegaban con la proa dirigida a las Cíes. El lugar era tan adecuado, entre dos promontorios petreos, A Laxe y San Francisco, que daba seguridad a sus frágiles embarcaciones. Acaecía esto allá por 1700. (PABLOS: «El Berbés, cuna de la ciudad» Faro de Vigo. 11-XI-96).

... se asegura por tradición constante del país que viene de unos en otros haberla fundado [la villa de Bouzas] gente de la mar vecina de Redondela por la mejor comodidad que ofrecía el sitio para salir á pescar; pero no espresan el tiempo en que se hizo esto mas convienen en que ha sido mucho antes de poblarse Vigo, ... (ÁVILA Y LA CUEVA, F.: Historia de Tuy y su Obispado. Tuy, 1852. Manuscrito conservado en el A.C. de Tuy, Vol. 2, fol. 203).

"CUADERNOS DE ESTUDIOS GALLEGOS", Tomo XLVII, Fascículo 113, Santiago 2000. 


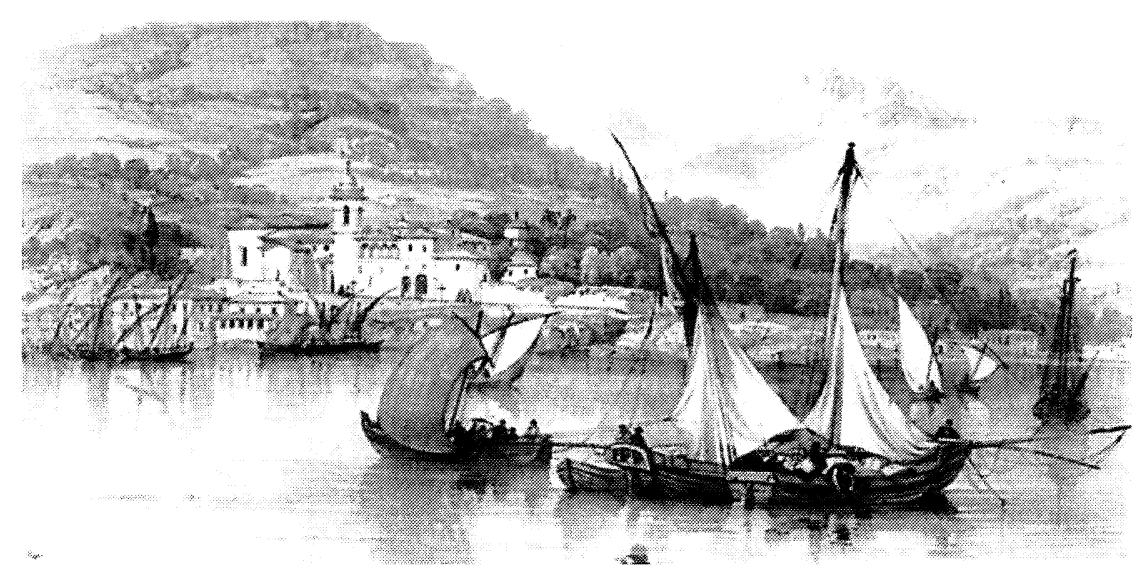

Vigo. O Berbés junto al convento de S. Francisco. (Primera mitad s. XIX).

Desde el siglo XVI el puerto de Vigo continuaría su desarrollo pesquero y comercial, que lo llevaría a competir con la realenga Bayona y, más tarde, tras múltiples altibajos, a convertirse definitivamente en el gran puerto atlántico que hoy conocemos.

Es de notar como en este conflicto, y junto a las iglesias de Redondela y Vigo, entra la iglesia de Reboreda, parroquia documentada desde mediados del siglo XIII, que tenía como anejo la iglesia de San Martín de Ventosela $^{59}$. En el siglo XV dicha iglesia era de presentación de legos, derecho que ostentaba el linaje de los Prego de Montaos, probado ya en 1443, año en que presenta doña Constanza Prego y, más tarde, en 1493, cuando lo hace su nieto y heredero D. Alvaro de Barcia (o Barçia), el mismo que había sido algún tiempo atrás Castillero del Arzobispo Fonseca en la fortaleza de Castricán cuando fuera tomada por D. Pedro Madruga.

${ }^{59}$ En 1493 era conocida como anejo de Sta. María de Reboreda, y así continuó hasta 1786, en que se erigió como parroquia independiente junto con los dos lugares inmediatos, Vilardemato y Castiñeira, a instancias del obispo D. Domingo Fernández Angulo. (ÁVILA Y LA CUEVA, op. cit., fol. 456). Hay un Auto previo sobre la desmembración de este anejo de su matriz, Sta. María de Reboreda, firmada por el mismo obispo dos años antes, en 1784. (ÁLVAREZ FERNÁNDEZ, Dolores: «Documentos sobre tres iglesias barrocas del Arciprestazgo de Redondela». El Museo de Pontevedra. Tomo XLVI (1992), págs. 303-304).

"CUADERNOS DE ESTUDIOS GALLEGOS", Tomo XLVII, Fascículo 113, Santiago 2000. 
Los Prego de Montaos mantuvieron siempre este patronazgo (no sin enfrentarse a continuos pleitos por su posesión), excepto en una ocasión, por permuta temporal con el Cardenal de Santiago D. Juan de Mondragón, que pudo usar de este derecho desde 1512 y llevó a cabo la primera ampliación de la iglesia ${ }^{60}$.

No obstante, en el momento de la presente sentencia (1494) era Rector del Beneficio de Santa María de Reboreda el Canónigo Morgued Juan, quien había obtenido el beneficio por presentación realizada el año anterior y participaba en el pleito como titular y como procurador del cura de Redondela.

Esta parroquia, que limita con la villa de Redondela formando hoy parte de su municipio, estaba íntimamente ligada a ella, hasta tal punto, que buena parte del espacio urbano de la villa se encontraba bajo su jurisdicción eclesiástica. En 1904 se produjo una nueva ordenación parroquial que agregó a la iglesia de Santiago de la Vilanova de Redondela aquellas calles del área urbana que anteriormente pertenecían a la feligresía de Reboreda ${ }^{61}$.

Ello explicaría el interés del rector de esta feligresía en el tema, ya que a pesar de no ser en apariencia una parroquia marítima, bajo su jurisdic-

\footnotetext{
${ }^{60}$ Según otros testimonios, el patronazgo habría pasado también, por merced real, a la Casa de Soutomayor, aunque por poco tiempo, puesto que este derecho le sería confiscado -según esos mismos testimonios- a D. Pedro de Soutomayor, nieto de Pedro Madruga, probablemente al ser condenado en 1518 como inductor al asesinato de su madre Doña Inés de Monroy. Sin embargo, no hay prueba alguna que confirme tal posesión y presentación por los Soutomayor. Además, por esos años era Don Juan de Mondragón quien detentaba ese derecho. (A.H.D.T., copia del Pleito Impreso (1736 a 1745), titulado: «POR/ DON BERNARDINO JOSEPH/Y DON BALTHASAR RAMON PEREYRA/ Y PREGO, SU HERMANO/ CON/ EL FISCAL DE EL REAL CONSEJO/ DE LA CÁMARA, Y EL DOCTOR DON MANUEL/ DE NORIEGA Y MIER/ SOBRE/ EL PATRONATO Y REPRESENTACIÓN/ DEL BENEFICIO CURADO DE SANTA MARIA DE REBOREDA, Y SU/ANEXO SAN MARTIN DE VENTOSELA, EN LA DIÓCESIS DE TUY").

Véase también GONZÁLEZ SANTISO, Aquilino: «Heráldica en las iglesias del Obispado de Tui», en Tui, Museo y Archivo Histórico Diocesano. Tomo IV (1989), págs. 261-263.

${ }^{61}$ Hasta 1904, en que se realiza la reorganización parroquial, las calles Rua do Val o do Medio (Isidoro Queimaliños), Rua do Riveiro (Reveriano Soutullo), Meixón Frío, Oriente (Telmo Bernárdez), Campo das Redes, Eidos, etc., pertenecían total o parcialmente, en lo eclesiástico, a la parroquia de Reboreda.
} 
ción eclesiástica vivían pescadores y mareantes que, en realidad, eran vecinos de la villa de Redondela, casi todos residentes en la rua do Ribei$r o^{62}$. Aún a mediados del siglo XVIII, según el Padre Sarmiento, aparecían censados en la Subdelegación Marítima de Redondela diecisiete marineros y seis embarcaciones de Reboreda ${ }^{63}$, por lo que también debían dar a su iglesia la parte correspondiente al diezmo del pescado.

Reboreda y las villas de Redondela y Vigo son los lugares protagonistas de la cuestión, pero no parecen ser los únicos. El documento muestra la participación -de forma generalizada- de otras feligresías de la diócesis, ampliando la dimensión espacial y la transcendencia del problema.

Tal participación se expresa cuando los vecinos de Redondela dan poder a su procurador Juan Cremenco para que en unión del procurador vigués e con os outros procuradores dos Vales, e freiguessias deste obispado, se encargue de concertar e ygoalar con sua señoria el obispo, de manera que puedan llegar a un acuerdo en el pleito e debate, que hera e se esperava ser ao diante, y que se llevaría a cabo con sua señoria e con todos los Clerigos beneficiados do dicto obispado de Tuy, por la disputa surgida sobre la rroupa da cama, e pano de menefesto e sobre outra qualquer coussa que entre ellos e os clerigos do dicto obispado y el abad de Redondela se encontraban movidas e demandadas, así como también sobre los dizimos e dereituras que se han de pagar a nosos Abades, como se debe pagar, e en que maneira... .

Sin embargo, estas otras feligresías y sus procuradores no aparecen mencionadas en el resto del pleito ni en la resolución y sentencia final del mismo, seguramente por haber sido tratadas de forma individual o colectiva en otros documentos.

${ }^{62}$ SOTELO RAMOS, Alfonso: Arquitectura y Urbanismo en Redondela. Guía didáctica $\mathrm{n}^{\circ} 3$. Concello de Redondela, Vigo, 1986, pág. 5.

${ }^{63}$ Viaje a Galicia de Fray Martín Sarmiento (1754-55), edic. de Sánchez Cantón y Pita Andrada. Santiago, 1950, págs. 94-95. Sarmiento da unas cifras que otras fuentes oficiales, cuatro años más tarde, reducían a la mitad. (Véase MEIJIDE PARDO, Antonio: «Aspectos de la vida económica de Vigo en el s. XVIII», en Vigo en su Historia, op. cit., pág. 305).

"CUADERNOS DE ESTUdIOS GALLEGOS", Tomo XLVII, Fascículo 113, Santiago 2000. 
A finales del siglo XV y principios del XVI en Galicia se opera un resurgir económico en el que se consolida una importante recuperación agrícola y demográfica. Este resurgir no fue ajeno, probablemente, a la finalización de las luchas internas que asolaron la región y que habían provocado una inseguridad perjudicial para las actividades comerciales ${ }^{64}$.

La recuperación afecta también a las poblaciones costeras, especialmente las del litoral occidental y las rías bajas, que registran a lo largo del siglo XVI las mayores concentraciones de población ${ }^{65}$. Es, pues, un momento de intensa actividad económica en el que hay una creciente demanda de pescado para la exportación, que genera riqueza y que provoca conflictos y tensiones entre los sectores sociales implicados ${ }^{66}$.

Por una parte, se va a producir una mayor competencia por los caladeros y los derechos de pesca entre las diferentes comunidades pesqueras de las rías, que devendrán en abiertos cónflictos solo parcialmente resueltos por las ordenanzas y acuerdos sobre el tema. Por otra, la nobleza y la Iglesia intensifican sus esfuerzos -aunque esta tendencia ya es anteriorpara controlar algunos núcleos, al tiempo que tratan de fundar y potenciar pequeños puertos situados bajo su directa jurisdicción (como el de Bouzas, auspiciado por el Obispo y el Cabildo de Tuy) para participar así de los beneficios ${ }^{67}$.

${ }^{64}$ Véase SAAVEDRA FERNÁNDEZ, Pegerto: «O Mundo Rural no século XVI: Crecemento da poboación e restauración da actividade agraria», en Galicia-Historia. Tomo III. Hércules de Ediciones. A Coruña, 1991, pág. 52.

${ }^{65}$ Ibidem págs. 64-66.

${ }^{66}$ FERREIRA PRIEGUE, op. cit., págs. 132 y 142, y SAAVEDRA FERNÁNDEZ, op. cit., págs. 138-139.

${ }^{67}$ FERREIRA PRIEGUE, págs. 347-349.

El mismo obispo de Tuy, D. Pedro Beltrán, y su Cabildo deciden en 1501 dar libertades y franquicias a todos los que viniesen a poblar el lugar llamado de Bouças (Bouzas) con sus redes y barcos o a ejercer sus oficios en tierra. La concesión incluía privilegio de carga y descarga y la creación de un alfolí de la sal. Probablemente con esta población se trataba de contrarrestar la influencia que el Arzobispo de Santiago tenía sobre las villas y el litoral de Vigo y Redondela, beneficiándose asimismo de las rentas que se derivarían de la potenciación de este asentamiento, ejerciendo la jurisdición directa sobre un puerto pesquero bien situado y en expansión. Además, se eximía a sus habitantes de todas las luytosas panos e camas de manifesto en las mismas condiciones que a Vigo y a Redondela, debiendo pagar igualmente el diezmo de pescado en la proporción de quince - uno. (A.C.T., Apeos. Tomo 53 (157). Texto publicado por IGLESIAS ALMEIDA, Ernesto: «El tráfico y pesca en los puertos de la Ría de Vigo. Contribución al conocimiento de su 
Es en este contexto, que los titulares de algunas feligresías costeras en auge ven, posiblemente, la oportunidad de actualizar los ingresos que obtenían por diezmos y otras rentas y derechuras. Estas, debido a su carácter proporcional, suponían unos beneficios en crecimiento, que en muchos casos se habrían mantenido disminuidos por falta de atención o por no hallarse claramente establecidas dichas rentas, y por la resistencia de los parroquianos a satisfacer unos gravámenes onerosos y a veces de origen confuso. De este modo, se intenta evitar esa dejadez e inconcreción, exigiéndose con fuerza y poniendo en claro aquellos derechos que los rectores eclesiásticos consideraban les eran debidos, dando lugar a que en ocasiones surgieran disputas sobre la tributación eclesiástica y también señorial. Con frecuencia, ésta pertenecía a varios señores, como en el caso de la villa de Muros por ejemplo, que en 1500 mantenía una querella con el Cabildo de'Santiago acerca de los diezmos del pescado correspondientes al beneficio de San Pedro, que detentaba D. Fernando Bermúdez de Castro ${ }^{68}$.

Y es que este litigio no es un fenómeno aislado. Se promueve en algunas feligresías del Obispado de Tuy, principalmente en dos importantes villas de la orilla sur de la ría de Vigo, pero se manifiesta también, de forma muy parecida (por no decir prácticamente igual), y con muy pocos años de diferencia, en la orilla norte de la misma ría, ya en territorio de la Archidiócesis Compostelana.

Allí, son los vecinos del puerto y bahía de Cangas los que se enfrentan a los titulares de la parroquia de Santa María de Darbo, a la cual pertenecían después de haber sido anexado a la Mitra Compostelana. Conocemos este caso por las referencias y el resumen que sobre él publicó D. Manuel Rodal, historiador local cangués, en un diario de Vigo ${ }^{69}$.

historia». El Museo de Pontevedra. Tomo XLIV (1990), págs. 663-691). La creación de este puerto provocaría graves tensiones con Vigo, que vio amenazados sus intereses pesqueros y de salazón.

${ }^{68}$ GARCÍA ORO, J.: Diego de Muros III y la cultura gallega del siglo XV. Ed. Galaxia. Vigo, 1976, págs 44-45. (Incluso en la Diócesis tudense, en 1528, el Arcediano de Miñor entabla un litigio por las Luctuosas de la Colegiata de Bayona, sentenciando contra él y a favor de la Dignidad Episcopal el Provisor Alonso de Peñaranda. FLÓREZ, op. cit., tomo XXIII, pág. 23).

${ }^{69}$ RODAL, Manuel: «El puerto pesquero de Cangas en el siglo XV. Los vecinos ya se negaban por entonces a pagar los diezmos del mar». Faro de Vigo. 24-VIII-96.

"CUADERNOS DE ESTUDIOS GALLEGOS", Tomo XLVII, Fascículo 113, Santiago 2000. 

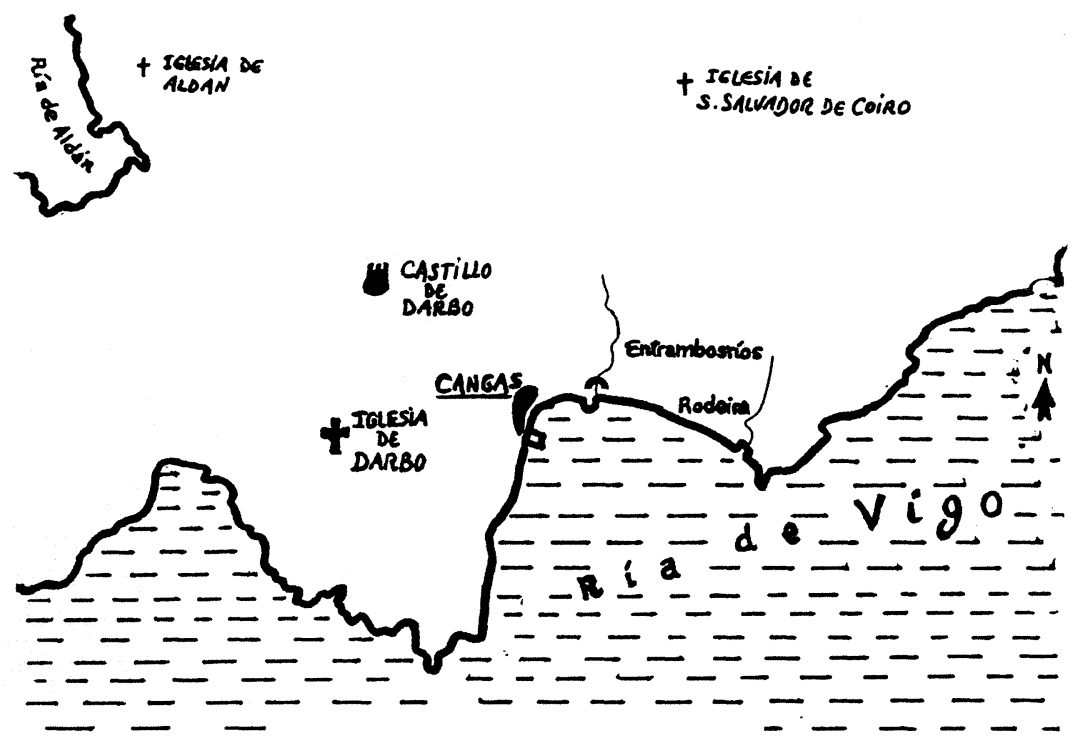

Área de Cangas a finales del s. XV.

Alrededor de 1490, Alonso de Fonseca III, Arcediano de Cornado ${ }^{70}$ (futuro arzobispo de Santiago) y clérigo de la parte «sin cura» de Santa María de Darbo, dio poder a Alonso González, cardenal, clérigo de la parte «con cura», para que solucionase el conflicto surgido con los feligreses.

Según Rodal, los vecinos del puerto y bahía de Cangas poco contribuían con los diezmos del mar a su parroquia, hecho imputable-según el autor- a la lejanía entre la parroquia y los feligreses. Sin embargo, sus rectores, viendo que cada día abundaban más los forasteros y mercaderes, y las constantes exportaciones que los mareantes realizaban a Valencia, Barcelona,Aveiro... etc., decidieron dialogar y llegar a un acuerdo con los moradores, vecinos y feligreses sobre el cobro de los diezmos, tratando de agruparlos en su parroquia. Esta actitud -continua Rodal- provocó la inmediata protesta tanto de los fieles de Cangas como de Darbo, que se

${ }^{70}$ La fecha de 1490 es la única que el Sr. Rodal menciona en su artículo, pero D. Alonso de Fonseca -según otras fuentes- fue nombrado Arcediano de Cornado en 1496. En cualquier caso, se constata la coincidencia de fechas y la similitud del conflicto cangués con el que se produce en las villas de Redondela y Vigo. 
negaron a pagarlos, aceptando tan solo el pago del diezmo de derecho divino, tal como lo hicieran sus antecesores.

Después de un tiempo se llegó a un acuerdo basado en los siguientes puntos:

1) Los diezmos no se pagarían con una unidad de cada diez, sino con una de cada catorce unidades.

2) Si aceptaban los diezmos, quedarían exentos de los paños loitos.

3) Los congrios que se pescasen se dispondrían en «tranderas» (trandeira, madero o pescante en el que se colgaban?) divididos en tres partes: grandes, medianos y pequeños, y de cada parte se cogerían uno de cada catorce.

4) Las sardinas de los cercos se pondrían en la ribera y allí los clérigos irían a por ellas. Lo mismo harían con el pescado de los trasmallos.

5) Si la venta del pescado fresco se hiciese en otros lugares no controlados por los clérigos el pago habría de hacerse en dinero, en la misma proporción del diezmo, una vez llegados a puerto, y el «maestro» o señor del barco debía responsabilizarse de ello.

6) $\mathrm{Si}$ anduviesen al oficio del xeito y regresasen de noche con poca captura que no diera para hacer un «quiñon» de catorce-uno, los mareantes podrían tomarla para sí.

Además, si tuvieran pleitos con los portugueses, se les prestaría asistencia para resolverlos.

El funcionamiento del puerto y bahía de Cangas estaba estructurado por las pesquerías del cerco, lanchas del cerco, dornas del congrio y del pulpo, juntamente con los grupos de pescadores y gentes de tierra ${ }^{71}$. Era un puerto dinámico que se había desarrollado a lo largo de todo el siglo $\mathrm{XV}$, alcanzando un buen nivel de capturas y también de exportaciones, que realizaba operando en colaboración con Pontevedra. Paralelamente, sus pescadores se caracterizaron por su belicosidad, numerosas veces enfrentados a los de otros puertos de la ría y de la vecina ría de Pontevedra, en constante pugna por ampliar los caladeros ${ }^{72}$.

\footnotetext{
${ }^{71}$ Ibidem Rodal, art. cit.

${ }^{72}$ FERREIRA PRIEGUE, págs. 133-134, y FILGUEIRA VALVERDE, J.: Archivo de Mareantes. Museo de Pontevedra-Instituto Social de la Marina. Pontevedra, 1946, págs. 223-226 y $230-231$, etc.
}

"CUADERNOS DE ESTUdIOS GALLEGOS", Tomo XLVII, Fascículo 113, Santiago 2000. 
A pesar de que el extracto publicado por el Sr. Rodal no es del todo completo y su redacción es algo imprecisa, pueden observarse las muchas coincidencias con el pleito objeto de nuestro estudio, coincidencias que ponen en evidencia el común rechazo de los marineros de los distintos puertos hacia este tipo de exacciones; no hay que olvidar que ya en 1406 los mareantes de Pontevedra habían solicitado del monarca D. Juan II la exención del diezmo a todo pescado ${ }^{73}, \mathrm{y}$ mantuvieron durante el siglo XVI algunas actitudes de incumplimiento y retrasos en los pagos. Por ello, este tipo de «arreglos» a los que asistimos debieron producirse de manera similar en otras partes, manteniéndose casi inalterados por lo menos hasta finales del siglo XVIII.

Fue en este siglo cuando la aparición de los fomentadores catalanes transformó los sistemas gremiales de trabajo y las relaciones económicosociales de los mareantes y pescadores, determinando un cambio de posición frente a la obligación del pago del diezmo.

Los pescadores se negarían a satisfacerlo alegando su condición de asalariados, no propietarios del pescado ni de los barcos y aparejos. Los catalanes -a quienes reclamó entonces la Iglesia-acabarían resistiéndose también, puesto que, según argumentaban estos fomentadores, sus actividades eran de transformación (salazón y comercialización) por medio de operarios y no de extracción directa de los frutos del mar.

Estos y otros argumentos presentados por los catalanes y contestados por la Iglesia llevarían a un conflicto que no terminaría hasta la extinción del diezmo del mar en $1828^{74}$.

El litigio se enmarcaría también dentro de un conflicto más amplio que ya venía produciéndose desde antes de mediados del siglo XV.

\footnotetext{
${ }^{73}$ Ibidem FILGUEIRA VALVERDE, pág. 155. (Sobre otros pleitos y demandas acerca de los diezmos, págs. 155 a 160). Lucas Labrada cita una Real Cédula del mismo D. Juan II, expedida en 1408, según la cual la pesca que se hacía en los puertos del Arzobispado de Santiago, y aún la que se internaba desde ellos, estaba exenta del derecho de diezmo. (LUCAS LABRADA, José: Descripción económica del Reino de Galicia. Ferrol, 1804. Ed. Galaxia, Vigo 1971, pág. 252). No tenemos, sin embargo, confirmación ni indicios de que tal Cédula llegara a aplicarse.

${ }^{74}$ SANTOS CASTROVIEJO, Santiago: Historia da pesca e a salgazón nas Rías Baixas dende as Ordenanzas Xerais da Armada de 1748 ata o desestanque da sal de 1870. Unipro Editorial, Vigo, 1990, págs. 53-56.
}

"CUADERNOS DE ESTUDIOS GALLEGOS", Tomo XLVII, Fascículo 113, Santiago 2000. 
De esta época es el llamado pleito de los arrianos o labradores, los cuales se enfrentaron al Cabildo y clero de la diócesis tudense durante años, al parecer debido principalmente a las dificultades que aquellos ponían para satisfacer los derechos de luctuosa, manifestados primordialmente sobre las camas e pannos postomeros ${ }^{75}$.

Las noticias sobre este pleito, que debió adquirir gran extensión y afectar a la mayoría de los campesinos, pertenecen a los años 1434 a 1464. En él acabarían implicándose de forma decidida algunas villas del Obispado, como Bayona y A Guarda y, de manera más cautelosa, la propia ciudad de Tuy, que fueron sometidas a «entredicho» ${ }^{76}$.

El entredicho, que en un principio se extendió a todo el obispado, fue quitado en 1462 de la ciudad de Tuy, limitándose a las villas, feligresías y lugares recalcitrantes. Finalmente, parece que entre 1463 y 1464 los arrianos obtuvieron la absoluciőn de las censuras eclesiásticas a que habían sido condenados, desapareciendo en ese último año las noticias documentales sobre el tema.

Previamente, los arrianos habían recurrido al rey, de quien obtuvieron cartas favorables, por lo que el Cabildo hizo también apelación a la corte, al tiempo que se mantenía receloso de la actitud del Obispo D. Luis de Pimentel. El prelado, refugiado en Astorga desde 1451 debido a las presiones ejercidas por Alvaro Paez de Soutomayor, no había satisfecho la cuantía que le correspondía en el repartimiento general que se había hecho entre todo el clero de la diócesis para la ajuda de se defendere dos arianos y se negaba a contestar las cartas del Cabildo. Este, por su parte, llegó a amenazar al obispo, caso de no ponerse a su favor, de nunca lle darem luitosa de ninguna persona nem canonico que entre elles se finase e que se el fase contra elles que tambem seerian contra el ${ }^{77}$.

Las Constituciones del Obispo Don Pedro Beltrán, ya citadas, redactadas a finales del siglo XV, insisten en la obligación del pago de las luctuosas. En dichas Constituciones se manda a los titulares de las iglesias que a aquellos feligreses que denieguen tales derechos no les fagan oficio nin beneficio de la madre Santa Iglesia, ni los entierren en Sagrado..., como

\footnotetext{
${ }^{75}$ Acerca de este pleito véase la interesante información suministrada por GALINDO ROMEO, Pascual: Tuy en la Baja Edad Media. Siglos XII-XV, op. cit., págs. 58-60.

${ }^{76}$ Sobre su significado véase infra nota 82.

${ }^{77}$ GALINDO ROMEO, pág. 59.
} 
así lo mandan las Bulas de Paulo II («Cum in omnibus») y Sixto IV («Et si universis») de los años 1465 y 1474 respectivamente, y bajo pena de excomunión para los mismos clérigos ${ }^{78}$.

La gravedad de las penas que se imponen y el testimonio que representan el pleito y sentencia que aquí se transcribe, demuestran que aun no se había resuelto totalmente la disputa de las luctuosas, ¿o fue quizás este pleito una consecuencia de la Constitución citada?. En cualquier caso, los núcleos urbanos parecen recibir un tratamiento más benévolo en la solución del conflicto, seguramente por su mayor capacidad de organización $\mathrm{y}$ de respuesta frente a los poderosos por parte de sus habitantes, con los que la Iglesia prefería ser un poco más cauta.

Además, la propia Iglesia tudense estaba realizando en este momento un esfuerzo de reorganización, tratando de recuperar bienes y rentas antes enajenadas de manera forzosa, en general, debido a la coacción desplegada por señores y escuderos -en especial la poderosa familia de los Soutomayor- que se habían adueñado del territorio.

Prácticamente, entre los años 1451 y 1487, la diócesis se había visto privada de sus prelados. Fueron casi cuarenta años de confusión durante los cuales, con certeza, se produjo una cierta relajación de las obligaciones económicas de los feligreses para con su Iglesia, la cual se encontró impotente para enfrentarse al expolio a que fueron sometidos sus monasterios, sus parroquias y el propio señorío temporal de los Obispos, a lo que cabría añadir la ignorancia y los abusos introducidos en la vida del clero y del pueblo ${ }^{79}$.

La desaparición, a partir de 1486, de D. Pedro Álvarez de Soutomayor («Pedro Madruga») de la escena del poder, y la nueva coyuntura política de pacificación propiciada por los Reyes Católicos, va a permitir unos años de estabilidad en la diócesis, aprovechados por su nuevo titular para tratar de volver a traer las aguas a su cauce.

El nuevo obispo pudo así cuidarse de recuperar algunos de los bienes eclesiásticos irregularmente enajenados y gestionar otras cesiones, sin olvidarse de atender la fábrica de la Catedral y de reorganizar el clero de la Colegiata de Bayona. Como complemento a las reformas disciplinares y pastorales que D. Diego de Muros había promulgado en el Sínodo de

\footnotetext{
${ }^{78}$ SYNODICON HISPANUM, op. cit., pág. 387.

${ }^{79}$ Ibidem, pág. 341.
} 
1482, estableció algunas constituciones sobre testamentos, luctuosas, protocolos notariales, canongías y diezmos. Asímismo, en una Asamblea eclesiástica celebrada en Vigo organizó su iglesia, haciéndola Colegiata, al tiempo que en otra constitución condenaba a un antiguo y peligroso enemigo del anterior obispo ${ }^{80}$.

Todas estas medidas -al igual que las del Sínodo de 1482-iban dirigidas tanto a los fieles como al mismo clero, y estaban dictadas por la necesidad de restablecer el orden eclesiástico y destinadas también a fijar con claridad cuales eran sus obligaciones. Sin embargo, se intentó llegar a un situación de equilibrio, que permitiera un consenso mínimamente beneficioso para ambas partes. Este sería el caso de la sentencia de 1494.

En el anexo de 1516, Payo Gomez de Soutomayor exige el cumplimiento de esta sentencia a los vecinos de Redondela.

Han pasado más de veinte años. A lo largo de este intermedio se ha producido la muerte del obispo en $1505 \mathrm{y}$, seguidamente, una delicada situación de «Sede Vacante» continuada hasta 1514, provocada por la obstinación de los monarcas hispanos en defender su derecho de patronazgo ante la curia romana, cuestión que afectó a diversas diócesis, entre ellas la tudense.

El Papa Julio II había proveído la Sede, al poco de vacar, en la persona de D. Juan de Sepúlveda, nombramiento que el rey D. Fernando no aceptó. En 1513 el Papa León X instó de nuevo al monarca para que D. Juan de Sepúlveda tomara, por fin, posesión de la diócesis, pero el monarca seguía negándose a darle el «placet» ${ }^{81}$.

Durante esta etapa, los capitulares tudenses vivieron tiempos de entredicho, afectando, parece ser, al cabildo y clero de la ciudad de Tuy (lo cual repercutía obviamente en los fieles) y solo en el recinto de la Catedral,

\footnotetext{
${ }^{80}$ FLÓREZ, Enrique: España Sagrada..., op. cit., Tomo XXIII, págs. 2-4 y 226-230, y SYNODICON HISPANUM, págs. 389-391. Sobre las otras constituciones, págs. 386388, 453-455 (atribuida a D. Diego de Muros en el Sínodo de 1528) y 476-477.

${ }^{81}$ HERNÁNDEZ MATÍAS, Antonio: «Vacante continuada y entredicho en el obispado de Tuy, (1505-1514). Documentos y notas adicionales». Tuy, Museo y Archivo Histórico Diocesano. Tui, 1989, págs. 117-119. (Véase también del mismo autor: «Luis Marliano (1463?-1521). Un Obispo de Tuy en la Corte de Carlos V», en COMPOSTELLANUM, XXXIXXXII (1-2). Santiago, 1986 y 1987, págs. 99-202 y 237-307 respectivamente, especialmente las págs. 172-189. El primer trabajo citado es continuación y complemento de éste).
} 
aunque no tenemos noticia documental acerca de las condiciones concretas de tal entredicho ${ }^{82}$.

Finalmente, en 1514, se nombraría Obispo en la persona de D. Martín Zurbano de Azpeitia, quien, al parecer, ya había estado en expectativa de ser nombrado Obispo de Tuy en 1506 y, aunque no llegó a nombrársele, era el que el Cabildo de Tuy esperaba ${ }^{83}$.

El nuevo Obispo tomó posesión de la diócesis en 1515, y es precisamente a partir de este momento, casi sin haber transcurrido un año, cuando D. Payo Gomez presenta su reclamación ante los vecinos de Redondela reunidos en su iglesia.

A ello contribuyó, seguramente, la estabilidad que el fin de la anómala situación de «Sede Vacante» prometía, y el respaldo que podía suponer la presencia efectiva del nuevo prelado. Las circunstancias se mostraban así favorables para que el rector de la iglesia de Redondela, y ya Arcediano de Miñor, pudiera efectuar la demanda. Sin embargo, el citado Obispo moriría en Madrid tan solo cinco meses después de presentada la reclamación, siendo nombrado para sucederle el italiano D. Luis Marliano, quien gobernó la diócesis por medio de procuradores desde su permanente ausencia en la Corte ${ }^{84}$.

${ }^{82}$ Ibidem, pág. 117 , nota 2 . Según este autor, el «entredicho» o «interdicto» es una censura o sanción eclasiástica en virtud de la cual se prohibe el uso (activo o pasivo) de las cosas sagradas, tales como la celebración del Oficio divino, la Eucaristía y demás Sacramentos y la sepultura eclesiástica, por parte de la persona, personas o entidad sobre las que se haya impuesto el entredicho. El decreto de imposición deberá determinar, en cada caso, si la prohibición es de carácter "personal»o «local», así como el carácter "particular»o "general» de cualquiera de ambas hipótesis.

Desde 1507 se mantenía este entredicho, ya que el cabildo no aceptaba ningún nombramiento sino se aportaban las bulas y documentos acostumbrados, lo que no podía ocurrir si se mantenía la oposición regia (Ibidem, 130-139).

En 1510, los representantes del preconizado obispo de Tuy, Juan de Sepúlveda, pronunciaron (¿un nuevo?) entredicho en el obispado por desacato al nuevo prelado. El regidor Juan da Voça y el procurador Pero Veloso recabaron del oficial espiscopal la anulación de esta grave censura eclesiástica que carecía de todo fundamento, pues no habían sido notificadas al cabildo las bulas de provisión del citado prelado. La reclamación se hizo en la catedral de Tuy, el 13 de Diciembre de 1510, decretando después el Vicario General, Lopo Rodríguez, nulo el entredicho. (A.G.S., Cámara-Pueblos, Tuy. Citado por GARCÍA ORO, J. y PORTELA SILVA, M.J.: Bayona y el espacio urbano tudense en el siglo XVI, op. cit., págs. 176-177 y nota 4).

${ }^{83}$ HERNÁNDEZ MATÍAS: «Luis Marliano (1463?-1521). Un Obispo de Tuy...», págs. 174-176.

${ }^{84}$ Ibidem, págs. 185-186.

"CUADERNOS DE ESTUDIOS GALLEGOS", Tomo XLVII, Fascículo 113, Santiago 2000. 


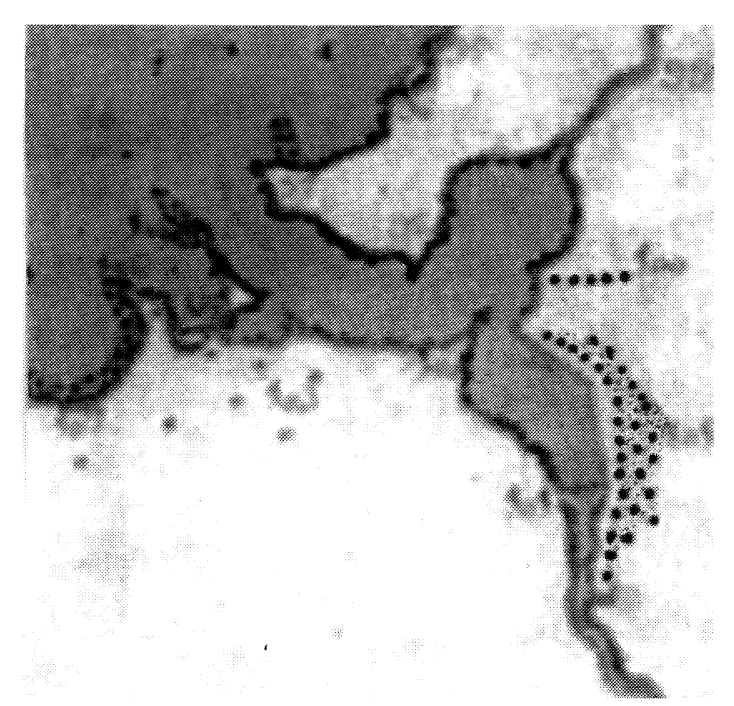

Detalle de la villa de Redondela sobre el brazo de mar o entrante de la ría, según plano de la misma del s. XVIII.

Los personajes que intervienen en el documento son bastante numerosos. Por un lado, los mareantes vecinos y moradores de las Villas, representados por sus procuradores; por otro, los rectores de las respectivas iglesias junto con la jerarquía eclesiástica de la Catedral de Tuy presidida por su Obispo.

Dada la cantidad de participantes y la transcendencia económica del resultado, no hay duda de la importancia de este litigio para ambas partes. Conocemos el nombre de bastantes de los vecinos de las villas (cuarenta y cinco de Redondela y quince de Vigo) y el de sus procuradores: Juan Cremenco (o Clemente) por los Redondelanos, y Afonso de Fornelos por los Vigueses, ambos vecinos de las villas que representaban.

Por la parte eclesiástica intervienen los rectores de las iglesias de Redondela, Vigo y Reboreda: Pai Gomes, Jacome Perez y Morgued Juan respectivamente.

Pai Gomes de Soto (o de Sotomayor), rector de las 3/4 partes «con cura» de la iglesia de Santiago de la Vilanova de Redondela, era un miembro segundón del linaje de los Soutomayor de la Casa de Lantaño. Aunque su nombre se presta a confusión, por haberlo llevado varios personajes de este linaje, sabe:nos que era hijo de Joan do Souto (o de Soutomayor) 
y de Urraca Estévez, y nieto por línea paterna de D. Diego Álvarez de Soutomayor o doutor ${ }^{85}$, bisnieto por tanto de D. Payo Gomez de Soutomayor, quien fuera embajador de Enrique III ante el Gran Tamerlán o Timur Lang (h. 1336-1405, soberano del segundo Imperio Mongol), y de Doña María Gomez, una de las princesas cristianas, al parecer de origen húngaro, que Tamerlán envió con los embajadores a su vuelta a Castilla ${ }^{86}$.

Por parte materna, Pai Gomes estaba emparentado con la familia Prego de Montaos de Redondela, familia de las más principales de la villa, existiendo muchos vínculos de parentesco entre los Soutomayor y los Prego de Montaos ya desde antiguo. Una de sus hermanas se llamaba Constanza Prego, casada con D. Juan Mariño. Otra hermana de Pai Gomez era María Sánchez de Soutomayor, casada a su vez con Loys Soga de Lobeira ${ }^{87}$. También era miembro destacado de esta familia el Arcediano de Cerveira D. García Prego de Montaos el Viejo, fundador del convento de la Purísima o de San Lorenzo Justiniano en la Vilavella de Redondela y capitular del Cabildo Tudense al mismo tiempo que Pai Gomes.

No tenemos noticia de cuando éste obtuvo el Curato de Redondela. Con el título de Clerigo cureiro aparece también en una «Avenencia» de $1496^{88}$. En este documento se dice también que Tristán de Montenegro (juez, regidor y alcalde de Pontevedra), ya fallecido, había sido tutor de Pai Gomez y sus hermanas; lo cual podría haber influido en el nombramiento, dadas las buenas relaciones habidas entre su tutor y el Arzobispo Fonseca II, a quien correspondería la provisión de las tres cuartas partes de la «con cura» de Redondela.

${ }^{85}$ 1496/12/11. Avenencia entre el convento de Santa Clara de Pontevedra y los herederos de Diego Álvarez de Soutomayor sobre bienes de éste. Doc. inédito. Archivo de Santa Clara. Pontevedra, sueltos.

(En 1416 el Arzobispo de Santiago dispensó a Diego Álvarez a fin de que pudiese obtener beneficios eclesiásticos. SALVADOR MARTÍNEZ, V.: «El Mariscal Don Suero Gómez de Sotomayor» M. P. ,II (1943), pág. 122).

${ }^{86}$ Véase VASCO DE APONTE: Recuento de las Casas Antiguas del Reino de Galicia. Introducción y edición crítica con notas de Manuel C. DÍAZ Y DÍAZ y equipo. Santiago de Compostela, 1986, págs. 111-113, espec. nota 22. También LÓPEZ ESTRADA, F.: Embajada a Tamorlán. Estudio y Edición de un manuscrito del siglo XV. Madrid, 1943, LIV-LVIII.

${ }^{87}$ Avenencia..., véase supra nota 85.

${ }^{88}$ Ibidem. 
A principios del siglo XVI, Payo Gomez se convirtió en Arcediano de Miñor en lugar de Lopo Martiz (o Martínez), siendo nombrado en 1508 Vicario «Sede Vacante» por renuncia del ya muy anciano Arcediano de Montes D. Vasco de Marzoo, el cual desde 1505, tras la muerte del prelado D. Pedro Beltrán, ejercía en el cargo junto a Jacome González de Pedroso ${ }^{89}$.

En Junio de 1509, (en unión con Jacome González, Thesorero Vicario del Dean, ambos como Vicarios generales en todo el obispado de Tuy y el Cavildo), proveyó la Merindad de A Guarda, vacante por ausencia permanente en Valladolid de Juan Brandón, su anterior Merino ${ }^{90}$. Ese mismo año, en el mes de Julio, fue protagonista, como encausado, de una ceremonia de absolución (no sabemos de que delito jurídico, pero no parece que tuviera que ver con el entredicho), aunque no conocemos el objeto del pleito ni el tenor de la sentencia, recibiendo dicha absolución en sesión capitular por parte del tesorero del propio Cabildo, el ya citado Jacome Gonzalez ${ }^{91}$.

Payo Gomez permaneció como Vicario «Sede Vacante» hasta 1511, año en que desde Redondela envió los sellos del Obispo de Tuy a los nuevos Vicarios S.V., el Maestrescuela Morgued Juan y el Racionero de la Iglesia de Tuy Lope Rodríguez ${ }^{92}$, este igualmente vecino de Redondela, quien también había sido el portador de la sentencia absolutoria antes citada en nombre del Obispo de Britonoro (Bertinoro, en Italia), Nuncio y Colector Apostólico en el Reino de Castilla.

Durante su curato, en 1511, se dio poder a dos personas residentes en Roma para que, con el permiso de feligreses y patronos, gestionasen que la iglesia de Redondela pudiera erigirse en Colegiata, agregándosele el

\footnotetext{
${ }^{89}$ FLÓREZ, op. cit., T. XXIII, pág. 8. ÁVILA Y LA CUEVA, op. cit. T. IV, fol. 109, etc.

${ }^{90}$ HERNÁNDEZ MATÍAS: «Luis Marliano...», op. cit., pág. 246.

${ }^{91}$ HERNÁNDEZ MATÍAS: «Vacante continuada y entredicho...», op. cit. págs. 136-137.

${ }^{92}$ HERNÁNDEZ MATÍAS: «Luis Marliano...», pág. 247. (Este Lopo o Lope Rodríguez aparece en 1526 testificando por parte del Arzobispo de Santiago, D. Juan Tabera, en el pleito Tabera-Fonseca. RODRÍGUEZ GONZÁLEZ, A.: Las fortalezas de la Mitra compostelana y los «Irmandiños». Instituto Padre Sarmiento de Estudios Gallegos. Pontevedra, 1984, tomo I, págs. 81-83).
}

"CUADERNOS DE ESTUDIOS GALLEGOS", Tomo XLVII, Fascículo 113, Santiago 2000. 
Beneficio de Reboreda en cuanto vacase; sin embargo, tal fundación nunca llegaría a efectuarse ${ }^{93}$.

Finalmente, en 1516, como ya sabemos, reclamó ante los vecinos y autoridades de la Villa de Redondela, que se encontraban reunidos en la iglesia de Santiago celebrando la Misa Mayor del Domingo, el cumplimiento de la sentencia dada en 1494. No sabemos si tal reclamación tuvo algún resultado inmediato, aunque sí sabemos que el veredicto continuaba acatándose en 1789 .

Jacome Perez, Clérigo Abad da Feligresía de Sta. María de Vigo, llevaba ya bastante tiempo como titular de la iglesia viguesa, pues como tal ya había asistido en 1482 al Sínodo convocado por D. Diego de Muros en la sede tudense ${ }^{94}$. Tres años después de la presente sentencia, en 1497, se produce la elevación a Colegiata de su iglesia, al tiempo de celebrarse en Vigo la Asamblea Eclesiástica (y no Sínodo), que estuvo abierta a clérigos y laicos ${ }^{95}$.

Según una de las Constituciones promulgadas en esa Asamblea, aquella que establecía la Colegiata, Jacome Pérez era Abad de la terçia parte con cura de dicha iglesia ${ }^{96}$, perteneciéndole por entero sus rentas y obvenciones. Sin embargo, debido al señalado aumento de población de la villa (e, indudablemente, también de sus rentas), el obispo decidía, personalmente y sin perjuizio del dicho Jacome Peres, suprimir y extinguir la abadía, ordenando y estableciendo en la mencionada iglesia un prior y

${ }^{93}$ A.H.D.T., copia del Pleito Impreso (1736 - 1745), op. cit.

${ }^{94}$ SYNODICON HISPANUM, pág. 385.

${ }^{95}$ Ibidem, 388. Las constituciones se leyeron en una función abierta a todos los que quisieran asistir, tanto clérigos como laicos, emanando tales constituciones de solo el Obispo, de ahí que tal función no pueda considerarse un sínodo ni las constituciones como sinodales, aunque después, en otros sínodos, fueran retomadas como tales.

${ }^{96}$ No obstante, en la sentencia que comentamos, Jacome Perez aparece como $\mathrm{Abad}$ da feligresia 'çencura' o como Clerigo Rector de la Yglessia parte 'çencura' de Santa Maria de Vigo, y los canónigos de Tuy se presentan en nome da dita sua Yglesia e mesa Capitular, e tenencia de Vigo, duas partes 'sencura'. Si las tres palabras entrecomilladas se interpretan como «sin cura», se contradice lo que expresa la dicha Constitución sobre la Colegiata, según la cual Jacome Peres es Abad de la terçia parte con cura de la dicha iglesia, cuyas rentas y obvenciones pertenesçian al dicho su terçio todo por entero, incorporando el obispo, al nuevo priorazgo, la dicha iglesia e beneficio tercia parte concura de la dicha Yglesia de Vigo.

"CUADERNOS DE ESTUDIOS GALLEGOS", Tomo XLVII, Fascículo 113, Santiago 2000. 
seis racioneros, incorporándola al priorazgo junto con el beneficio de la tercia parte «con cura».

Su primer prior sería el ya conocido Jacome Gonzales de Pedroso, en ese momento canónigo de la catedral de Tuy y por la santa Authoridad Apostólica e hordinaria publico notario. Entre los seis racioneros se encontraba también el clérigo Alvaro Vaasques, seguramente el mismo que figura aquí como uno de los testigos de Jacome Peres, y también Alvaro Mallo, hasta entonces (y desde 1469) párroco de Sta. Baya de Alcabre ${ }^{97}$.

Jacome Peres otorgó su consentimiento a todo lo dispuesto por el obispo y siguió, muy posiblemente, disfrutando de una parte de las rentas y participando en el culto de su iglesia hasta su muerte, ya que los racioneros solo podrían decir la Misa cantada a los Domingos mientras él viviese (y debía ser ya anciano), después deberían continuadamente cantar las oras, e missas, segund que se rege e esta ordenada la iglesia de Bayona,...

Morgued Juan (llamado también Morguet ó Morguete) es un personaje de nombre peculiar que aparece durante el episcopado de D. Pedro Beltrán y en los años posteriores en que estuvo vacante la sede. Es posible que llegara a Tuy con el prelado como su hombre de confianza, tal vez fuera mallorquín como D. Pedro. El caso es que desde el momento en que el nuevo obispo toma posesión de la sede, Morgued Juan actúa ya como Provisor, cargo de confianza que comparte con el propio hermano del obispo D. Guillermo Beltrán ${ }^{98}$.

Morgued Juan continuaba como Provisor en 1488, y en el momento de la sentencia se intitulaba como Canónigo, Provisor y Vicario general por el Obispo. Igualmente, en este año (1494), era ya Rector del Beneficio de la iglesia de Santa María de Reboreda (de la que, seguramente, siempre estuvo ausente) y Procurador de Payo Gomez.

Sin embargo, según Flórez, Morgued Juan recibió del prelado, en 1497, la Maestrescuelía de Tuy con el Beneficio de Redondela y su anejo99. Ávila y La Cueva, por su parte, aclara que debe leerse aquí en lugar de Redondela, Reboreda y su anejo, que es positivo le obtuvo, y no Redon-

\footnotetext{
${ }^{97}$ ÁVILA Y LA CUEVA, op. cit., T. IV, fol. 78.

${ }^{98}$ FLÓREZ, op. cit., T. XXIII, pág. 2.

${ }^{99}$ Ibidem.
} 
dela que nunca tuvo anejo alguno ${ }^{100}$. Nuestro documento corrobora la opinión de este último, pero corrige el año, al hacerlo titular de Reboreda ya en 1494.

En realidad, Morgued Juan obtuvo el beneficio en Enero de 1493, el día 2, fecha en que D. Pedro Beltrán despachó el título de dicho beneficio y su anexo a su Provisor, por presentación de Alvaro Barcia y otros Compatronos en número de sesenta y dos, tras el fallecimiento de su anterior titular Alvaro González. El nuevo rector tomó posesión el 3 de Enero de dicho año ${ }^{101}$.

En 1512 Morgued Juan permutó su beneficio con Juan de Mondragón, Canónigo de la Catedral de Santiago, que poseía el de San Salvador de Coiro (Arciprestazgo de Morrazo), para lo cual obtuvieron Bula del Papa (que derogó temporalmente el patronato de legos de los Prego de Montaos), entrando el canónigo compostelano en posesión del beneficio de Reboreda en junio de 1514.

Durante los años 1498 a 1501, Morgued Juan mantenía los cargos anteriormente mencionados y, posteriormente a la muerte de D. Pedro Beltrán, seguía apareciendo (en 1507 y 1509) como Maestrescuela entre los Canónigos del Cabildo. En 1511 fue nombrado Vicario «Sede Vacante» junto con Lopo Rodríguez, sustituyendo a Jacome Gonzalez de Pedroso y a Payo Gomez de Soutomayor. Con toda probabilidad, permaneció en el cargo hasta 1514, año en que por fin fue cubierta la vacante al nombrarse Obispo en la persona de D. Martín Zurbano (1514-1516), continuando como Maestrescuela, dignidad que conservó durante el mandato de este obispo y aún después, designándosele, al fallecer Zurbano, Collector Apostólico ${ }^{102}$.

\footnotetext{
${ }^{100}$ ÁVILA Y LA CUEVA, op. cit., T. IV, fol. 102.

${ }^{101}$ A.H.D.T., copia del Pleito Impreso (1736-1745), op. cit.

${ }^{102}$ Sobre la evolución de Morgued Juan, véanse los artículos de HERNÁNDEZ MATÍAS: «Vacante continuada y entredicho...», op. cit., págs. 133-137 y, «Luis Marliano...», op. cit. págs 146-248 y 250-251. Especialmente la parte documental de ambas obras. (En años posteriores (1528), aparece un racionero de la Catedral de Tuy, más tarde también Canónigo (1536), llamado Morguete Rodríguez, fundador en 1543 del vínculo y mayorazgo de A Picoña, el cual -salvo el nombre y oficio eclesiásticono parece tener relación alguna con el anterior. ÁVILA Y LA CUEVA, op. cit. tomo I, fol. 267).
}

"CUADERNOS DE ESTUDIOS GALLEGOS", Tomo XLV́II, Fascículo 113, Santiago 2000. 
D. Pedro Beltrán, obispo de Tuy de 1487 a 1505 y Arcediano de Nendos en la Catedral Compostelana, nació en la villa de Llucmajor, en la isla de Mallorca. Comenzó su carrera eclesiástica alcanzando una canonjía en la Catedral de Palma, época en la que también vacó y obtuvo la rectoría de la iglesia de su pueblo natal. De canónigo en Mallorca pasó a Oidor de la Real Audiencia de los Reyes Católicos, siendo promovido desde ese puesto al episcopado de la diócesis tudense ${ }^{103}$.

Nada más llegar a su sede nombró Provisores a Morgued Juan y a Guillermo Beltrán, su hermano, a quien también nombró su Vicario general, aunque éste ya llevaba varios años como Dean de Santiago y era además Protonotario Apostólico.

Durante su episcopado reorganizó la diócesis y resolvió una serie de contenciosos, algunos de los cuales habían quedado pendientes desde el accidentado pontificado de su predecesor D. Diego de Muros.

El 29 de Octubre de 1491 redujo el Cabildo de la Colegiata de Bayona $^{104}$ (instituida por D. Diego de Muros en 1482), dejándola con dos abades y doce racioneros de los catorce que tenía, confirmando el Papa InocencioVIII dicha reforma y rango de Colegiata mediante Bula expedida en Roma el 9 de Abril de $1492^{105}$.

En 1494, luego de volver de un viaje a Castilla, actúa como juez, Arbitro Arbitrador e Amigable conponedor, en el pleito que nos ocupa, dando sentencia para resolver el conflicto aquí analizado.

Encontrándose en la Asamblea Eclesiástica de Vigo, celebrada en el mes de Junio de 1497, elevó a rango de Colegiata la iglesia de Sta. María, en atención al aumento del número de feligreses. Dos años más tarde, en Octubre 1499, concluyó la obra de la Capilla mayor y las capillas de Santiago y San Pedro en la Catedral de Tuy.

En Febrero de 1501, en unión con el Cabildo Catedralicio, dio libertades y franquezas a todos aquellos que decidiesen ir a poblar el lugar de Bouzas, potenciando así su puerto y creando una nueva villa litoral

${ }^{103}$ Sobre este obispo y su pontificado en general, véase: FLÓREZ, op. cit., T. XXIII, págs. 2-6, y ÁVILA Y LA CUEVA, op. cit., T. IV, fols. 81-108.

${ }^{104} \mathrm{Da}$ esta fecha, MENDEZ CRUCES, Plácido: «Heráldica de la catedral de Tui. Dos notas». Boletín del Seminario de Estudios Fontan-Sarmiento n 13 (1992), pág. 95.

${ }^{105}$ FLÓREZ, op. cit., T. XXIII, págs. 220-226.

"CUADERNOS DE ESTUDIOS GALLEGOS", Tomo XLVII, Fascículo 113, Santiago 2000. 


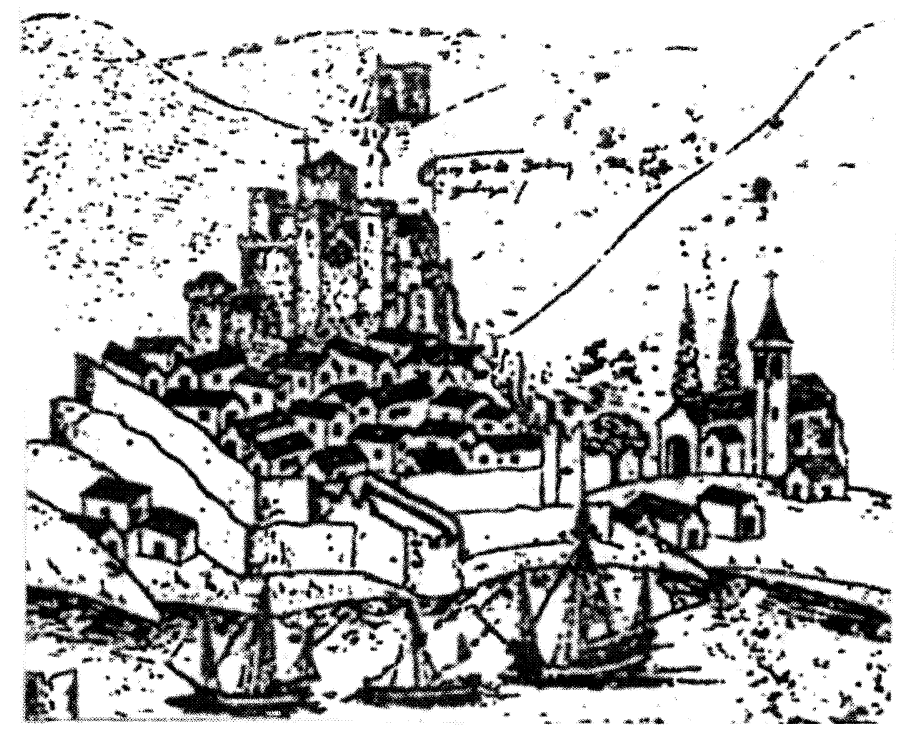

Tuy según un dibujo de 1502 del portugués Duarte Darmas.

(en parte para contrarrestar la influencia del Arzobispo de Santiago en la ría de Vigo y beneficiarse asímismo del floreciente tráfico pesquero y comercial que otras poblaciones disfrutaban), la cual pronto entraría en competencia y grave conflicto con la vecina villa de Vigo ${ }^{106}$.

En 1504 D. Pedro Beltrán comunicó al Cabildo que partía de viaje hacia la Corte de Roma, donde al parecer murió al año siguiente, habiendo constancia de la vacante desde el mes de Abril de $1505^{107}$.

Algunos otros personajes, especialmente los eclesiásticos, aparecen en otros documentos anteriores y posteriores a la sentencia, pudiéndose apreciar, a veces, la evolución de su carrera.

Interesante es el caso del anciano Arcediano de Miñor, D. Lopo Martiz, quien recuerda de forma expresiva en 1502 como aproximadamente unos veintisiete años atrás hubo de enfrentarse con el temible Pedro Madruga, el cual le había amenazado con graves castigos si no le firmaba un poder

\footnotetext{
${ }^{106}$ Véase supra nota 67.

${ }^{107}$ HERNÁNDEZ MATÍAS: «Vacante continuada y entredicho...», op. cit., págs. 118 y $120-122$.
}

"CUADERNOS DE ESTUDIOS GALLEGOS", Tomo XLVII, Fascículo 113, Santiago 2000. 
que permitiría al Conde vender una elevada cuantía de bienes eclesiásticos, cediendo finalmente el Arcediano, y con gran susto, a las coacciones del noble ${ }^{108}$.

En total son 90 las personas citadas en el texto, llegándose casi a las 100 si se suman las del anexo de 1516, y muchas más que no se citan (para una visión más clara del conjunto de los personajes citados en el documento obsérvese el apéndice II). El conocimiento de sus nombres y apellidos tiene el valor añadido de permitirnos descubrir incluso la procedencia geográfica de algunos vecinos y su profesión.

Finalmente, este litigio nos muestra también, una vez más, como las sociedades urbanas no estaban exentas de tensiones ante el ejercicio del poder señorial tanto laico como eclesiástico, al que de una u otra forma se hallaban sometidas, y con el que mantenían una disparidad de intereses que daba lugar a conflictos que ponían a prueba su capacidad de respuesta.

${ }^{108}$ GALINDO ROMEO, op. cit., documento XXVIII, págs. XXIX-XXX.

"CUADERNOS DE ESTUDIOS GALLEGOS", Tomo XLVII, Fascículo 113, Santiago 2000. 


\section{APÉNDICE I EL DOCUMENTO}

1494, Julio, 20 - Agosto, 24. Redondela, Vigo, Tuy.

El obispo de Tuy, tras el compromiso y la presentación de las cartas de poder y procuración de las partes, da sentencia en el litigio suscitado entre los vecinos y feligreses de Redondela, Vigo y Reboreda con los abades de sus respectivas iglesias a causa del pago de la luctuosa, el diezmo y otras derechuras.

Colección particular de D. Alejandro Martínez Adán. Copia de finales del s. XVI ó principios del s. XVII. Papel. 312 x 220 mm. Letra humanística. Buena conservación. Inédito.

Ano do nacimento de noso señor Jesuchristo de mill e quatrocentos e noventa e a quatro anos, vinte e a quatro dias do mes de Agosto: Sepan quantos este publico ynstrumento de compromiso viren que os venerables e circunspectos señores Lopo Martiz,Arcidiano de Miñor, Vicario do Dean, don Pedro Martiz de Montes; Pedro Gonzales de Fuentes chantre; Juan de Santo Domingo, Thesorero; Basco de Marzoo, Arcidiano de Montes; Morgued Juan; Gonzalo Perez; Pedro Gonzales; Lopo de Cepeda; personas e canonigos da Yglesia de Tuy; e[n] nome da dita sua Yglesia e mesa Capitular, e tenencia de Vigo, duas partes sencura, e estando juntos ena claustra da dicta Yglesia, en seu lugar acustumado Capitularmente ajuntados por son de Canpana tagida segun que o an de seu boo uso e costume, e o dicto señor Morgued Juan, Canonigo, como rector do beneficio de Santa Maria de Revoreda, da Vila de Redondela, e eso mismo como procurador de Paigomes, rector de Santiago de Redondela, por virtud de un poder que logo presentou; ê Rodrigo Afonso Clerigo, e[n] nome e como procurador de Jacome Peres, Clerigo Abad da Feligresia Çencura de Santa Maria de Vigo, e Afonso de Fornelos, por si e en nome dos vecinos e moradores da Vila de Vigo, e Juan Cremente, esso mesmo e[n] nume e como procurador dos vecinos e moradores da Vila de Redondela, os quaes poderes logo eno dicto Cavildo presentaron, cuiu tenor uno en pos de otro de palabra a palabra es este que se sigue:

"CUADERNOS DE ESTUDIOS GALLEGOS", Tomo XLVII, Fascículo 113, Santiago 2000. 
Sepan quantos esta carta de poder e procuracion viren como yo Pai Gomes de Soto, Clerigo Rector de la Yglesia de Santiago de Redondela, por mi, e en nombre de la dicha mi Yglesia, otorgo e conosco por esta carta que dò todo mi poder cumplido, llenero, bastante, assi como lo yo he e tengo, e en la mejor manera e forma que puedo e devo delo otorgar de derecho al venerable señor Morgued Juan, canonigo en la Yglesia Cathedral de Tuy, Provisor oficial e vicario General en la dicha Yglesia e en todo el ôbispado de Tuy por el muy reverendo en Christo, Padre e señor dò Pedro Beltran, por la Gracia de Dios e de la Santa Yglesia de Roma ôbispo del dicho ôbispado de Tuy, ausente assi como se fose presente, para que por mi e en mi no[m]bre pueda parecer e paresca antel dicto muy Reverendo señor obispo azerca del debate e castion e demanda que eu trahia e trago con os freigueses de la dicha mi Yglesia de Santiago de Redondela, sobre los diezmos, e panos, e camas de la dicha mi Yglesia, y todas las otras cosas a ella pertenecientes e para que zerca dello pueda concordar e facer concordia con los dichos Freigueses o su procurador en su nombre e para consentir en todo lo que el dicho señor obispo sentenciar e ordenar azerca dello, e de lo a ello anejo e conejo e dependente e envargante con todas sus ynsidensias e dependencias, e para facer zerca dello todo quanto yo faria e diria, Razonaria, concordaria, consentiria e outorgaria presente siendo, e quan cumplido e vastante poder como he e tengo, para todo lo que dicho es, e para cada cosa e parte dello, tal e tan conplido lo do e otorgo por mi e e[n]no[m]bre de la dicha mi yglesia al dicho señor Morgued Juan, Provisor, e todo quanto por el dicho mi procurador fuer fecho, dicho, Razonado, concordado, consentido e ordenado, eu lo he e avere por firme e estabel e valedero, para agora e para todo tiempo, so obligacion de todos los vienes de la dicha mi Yglesia, que para ello obligo, y prometo de no hir ni venir contra ello ni contra parte dello agora ni en algun tiempo; relevando como relevo al dicho señor Morgued Juan, Provisor, mi procurador, de toda carga e satisdacion e fiadoria, so aquella clausula que es dicha en latin, Yudicium sisti yudicatum solvi ${ }^{*}$ con todas sus clausulas acostumbradas e oportunas, e porque esto seja firme, e no venga en duda, otorgue esta carta de poder e procuracion antel ynfrascripto notario, al qual ruego que la faga ô mande fazer, e la signe de su

* Hice el juicio resolví lo juzgado

"CUADERNOS DE ESTUDIOS GALLEGOS", Tomo XLVII, Fascículo 113, Santiago 2000. 
signo e a los presentes que sean dello testigos, fecha e otorgada fue esta carta en la Ciudad de Tuy, dentro de los Palacios obispales a dez e nueve dias del mes de Agosto; ano del nacimento de nuestro señor Jesuchristo de mill e quatrocentos e noventa e a quatro anos. Testigos que foron presentes llamados e rrogados Fernan PerezAlguacil del dicho señor ôbispo, e Afonsso Lopez (sobre línea: por ?) Presbitero e Gonzalo Afonso, e Gregorio do Barreiro Criados del dicho señor obispo, e otros: E eu Jacome Gonzales de Pedroso, Canonigo en la Yglesia Cathedral de Tuy, por la santa Authoridad Apostolica e hordinaria publico notario a lo que dicho es, e al otorgamento del dicho poder en uno juntamente con los dichos testigos presente fui, e este publico ynstrumento de poder e procuracion, segun que por ante mi pasò e fuè otorgado por mi mano, ô scrivi y sobre a escrivi, e signe, e firme de mi signo e no[m]bre acostubrados: En testimonio de Verdad Rogado e requerido Jacobus Gundisalvi de Pedroso, notario:

Sepan quantos esta carta de poder e procuracion viren como eu Jacome Perez, Abad y Cura e rector de la Yglesia de santa Maria de Vigo, Conozco e outorgo que dou todo meu poder cumplido e a bastante, e que fazo por meu procurador, segun que o eu mellor poso, e con derecho devo, a vos Rodrigo Afonso Clerigo, meu criado que presente estades (para que por mi en meu nome os posades presentar e presentedes) ${ }^{* *}$ personalmente con este dicto poder antel muy reverendo señor do Pedro Beltran, ôbispo de la Yglesia Ciudad e obispado de Tuy, e vos assi presentado posades estar e negociar, e procurar, e concertar todas e qualesquier cousas e cada una delas que fecere, procurare e negociare Los señores Dean e Cavildo e las otras personas e beneficiados de la dichaYglesia de Tuy con sua señoria e con Afonso de Fornelos, Procurador desta dicha Villa de Vigo, e facer todos e qualesquier autos e diligencias que a o caso convena de facer, ben assi e tan cumplidamente como se eu mesmo o fecese e procurase, aunque sejan tales e de tal calidad que para elo aja menester mais especial mandado e de derecto llo rrequeran, e para que podades estar a la sentencia e sentencias que por sua señoria foren dadas e pronunciadas e consentir en todo que los ditos señores Dean e Cavildo consentire e outor-

** Interpolación colocada a pie de página señalada con (a) 
gare, para o qual todo que sobre dito he e para qualquier cousa e parte delo vos dou e outorgo o dito poder cumplido e a bastante con todas sus ynsidencias, nigencias, e dependencias, anexidades e conexidades, relevado a vos, o dicto meu procurador, de toda Carga de satisdacion e fiadoria, e avedo por firme e rrato todo o por vos feito, dicto, Tratado, procurado e negociado, consentido e outorgado su aquela clausula dicta en latin, Yudicium sisti yudicatum solvi, con todas sus clausulas acostumbradas; en fe do qual ôtorguei esta carta de poder e procuracion por ante el notario e testigos de yuso escriptos, feita e outorgada ena dicta vila de Vigo, a vinte dias do mes de Agosto do ano del señor de mill e quatrocentos e noventa e quatro anos; Testigos que foron presentes Pedro Collazo, Afonso Fernandez, Rodrigo do Souto eAlvaro Vasquez, Clerigos e outros, e eu Juan de Pumar escrivano e notario publico del Rey e de la Reyna nuestros señores, e notario de la Villa de Vigo e su jurdicion por el muy Reverendissimo señor Arzobispo e Yglesia de Santiago, que a isto que sobre dito es con los testigos presente fui, e esta carta de poder escrivi ben e fielmente segun que por ante mi pasou, e aqui meu nume e signo fiz que tal es: En testimonio de Verdad Juan de Pumar notario.

Ano do nacimento de noso señor Jesuchristo de mill e quatro centos e noventa e quatro anos, a vinte e sete dias do mes de Jullio; sabran todos como nos Afonso do Outeiro, e Juan Solteiro, e Pedro Solteiro; e Afonso de Guodaran, e Juan Franco, Jacome de Bicedo; e Pedro Ribeiro; Juan Calvo da Ladeira, e Juan Gonzales Codeso, e Fernando de Bincios, e Seveiro Nuñez, e Juan de Villela, e Juan de Morrazo, e Juan Garcia, e Juan de Bouzas, fazentes por nos e por los outros mariantes vecinos e moradores en esta villa de Vigo, non rrevocando nosos procuradores que hasta aqui havemos feitos, e[n] nosos pleitos e qualquier delos, e en especial non rrenovando de noso procurador Afonso de Fornelos, outrosi Vecino e morador en esta dicta vila de Vigo, noso procurador, eno pleito e contenda que temos con el señor Pedro Beltran, ôbispo de Tuy, e con el Dean e señores del Cavildo e clerecia del, antes rretificando e avendo por firme e estabel todo quanto hasta aqui por lo dicto Afonso de Fornelos noso procurador foi feito, dicto, tratado, rrazonado, pedido e procurado por nos e en nosos numes, eno dicto negocio e pleito, e para que outrosi el dito noso procurador possa por nos e en nosos numes facer e faga concierto e yguala con el dicto señor ôbispo, Dean e cavildo e clerecia, sobre rrazon das 
camas e rroupas de bestir, que en esta dicta vila de Vigo soia a levar aos difuntos, e mais para que posa concertar e concerte con el dicho señor obispo, Dean e cavildo e clerecia, e Abad de Santa Maria de Vigo, para que nos, los dictos mareantes vecinos e moradores en esta Villa de Vigo, lles paguemos os dizimos de todos los pescados e sardina fresco en la Rivera, e para esto Terremos e compliremos e agardaremos, outorgamos esta Carta de poder ante o notario e Testigos a yuso scriptos so obligacion de Todos nosos bees mobles, e rraizes, que para ello obligamos e facemos e outorgamos por noso, cierto, a bastante e suficiente procurador ao sobredicto Afonso de Fornelos, e damoslle e outorgamoslle todo noso libre e cumplido poder e especial mandado para que el por nos e en nosos nomes en General ou en especial possa concertar e negociar e Arbitrar as dictas camas e panos de manifesto, e esso mesmo os dicimos dos pescados e sardinas frescos en la Riveira, e eso mesmo lle damos noso poder ao dicto Afonso de Fornelos, noso procurador, para que posa sobre esto que dicto he e sobre cada cousa delo frontar e protestar e estimar, conocer, negar, e tomar testimonio, e testimonios, protestacion e protestacioos, e facer, dicir e rrazoar todas las cousas e cada una delas que nos fariamos, diriamos e procurariamos, e tratariamos siendo nos a todo elo (sobre línea: mismos) presentes, con todas Clausulas e solegnidades que os derectos a elo ponen. E todo quanto sobre esto que dito he, e sobre qualquier parte delo por lo dito noso procurador Afonso de Fornelos feito for procurado ou outorgado, todo lo avemos e averemos por firme e estabel para siempre, e prometemos e outorgamos no hir contra elo so obligacion de todos nosos bees que para elo obligamos e para estar ao juicio e cumplir e pagar ho que contra nos for Juzgado; que foi feita e outorgada a dicta Cartta de poder ena dicta villa de Vigo, año, e mes, e dia, sobredictos. Testigos que foron presentes Nuño ${ }^{* * *}$ Vasquez, Juiz da dicta vila, e Pedro Mendez, procurador, e Ares Perez, Clerigo, e Afonso Martiz, Clerigo de San Pedro de Sardoma, e outros. E eu Afonso do Porto, notario e escrivano publico del Rey e Reyna, nuestros señores, enas suas Cortes e en todos los seus Reynos e señorios, a esto que dicto he, con os dictos testigos presente fui, e a pedimento dos sobredictos este poder fige e firmei de meu nume, que tal he; Afonso do Porto, notario.

*** Sobre escrito, debajo: Martiño?

"CUADERNOS DE ESTUdiOS GALLEGOS", Tomo XLVII, Fascículo 113, Santiago 2000. 
Sepan quantos esta Carta de Poder e procuracion viren como nos os vecinos e moradores da villa de Redondela, Conven a asaver los siguientes: Juan Milleiro, Alvaro Salgueiro, Pedro Gonzales Carpinteiro, e Duran de Moscojo, Martino Salgueiro, e Gonzalo do Casal, e Gonzalo de Ramirans, Afonso Rodriguez, Juan Bello, e Lorenzo de Moos, Lorenzo da Quaal, e Gonzalo de Lantano, Juan Crimeco, e Juan Francès; Antonio Ferreiro; e Juan Fernandez e Basco Preto; e Gonzalo Milleiro; e Juan Thomas Tezelan; e Gonzalo de Santa Maria, Martino de Nogueira e Pedro Fernandez; e Rolan: e Fernan Fragueiro, Estevo Guiraldez; e Juan de Mourelle; Estevo Balan, Juan Carneiro; Tharesa de Lavadores; e Rodrigo das Regadas; e Juan de Guntije; Gregorio de Junqueiras, Alvaro de Lira, ô mozo; Gonzalo Antre: Estevo Suares, Juan de Santabaia: Pedro Buxeiro, Gonzalo da Bouza, Juan Suares o mozo; Diego Diz; Martin Salgueiro, Bartholomeu Suares; Alvaro de Rouzas; Gonzalo Lourenzo, Alvaro de Nogueira; Vecinos e moradores ena Villa de Redondela; por aquellas mellores vias, forma, maneira, que nos podemos e con dereito devemos, Damos e outorgamos todo noso bastante conplido poder â Juan Cremenco, Vecino desta (sobre línea: dicta) Villa, Levador da presente, para que por nos e en nosos numes e de cada uno de nos, se possa presentar e presente antel Reverendissimo señor don Pedro Beltran, ôbispo de la Santa Yglessia e obispado de Tuy, con Afonso de Fornelos vecino de Vigo, procurador deste ôbispado de Tuy, e con os outros procuradores dos Vales, e freiguessias deste ôbispado, â concertar e ygoalar con sua señoria Uno pleito e debate, que hera e se esperava ser ao diante con sua señoria e con todos los Clerigos beneficiados do dicto obispado de Tuy, sobre la rroupa da cama, e pano de menefesto, e sobre outra qualquer coussa que entre nos e os clerigos do dicto obispado e noso Abad esta[n] movidas e demandadas para que o dicto noso Procurador posa con sua señoria ou con quen a sua señoria mandar, facer concerto, avenia, ygoala sobre estas cousas sobre dictas; e assi mesmo sobre los dizimos e dereituras que se han de pagar a nosos Abades, como se deve pagar, e en que maneira, para que o dicto noso Procurador possa zerca delo e de qualquer cousa e parte delo, facer, dicir, alegar, consentir, pedir e demandar, e para todo o que ansi en noso nume e de cada uno de nos con su señoria concertar e sentar posa ôbligar a nos e a todos nosos bees e de cada uno de nos, que nos teremos e gardaremos todo e quaesquer concerto, avenia ygoala que por lo de este noso procurador for feita, consentida, otorgada, o qual dicto poder lle damos 
con todas suas enxidencias, pendencias, enigencias, nexidades e conexidades anexas e dependencias a ellas, e con todas las outras Clausulas que a este poder de dereito so menester, posto que aqui no van expresas ni declaradas, nos has damos e outorgamos assi por escriptas e declaradas; e todo quanto por lo dicto noso procurador eno que dicto he, e en qualquer cousa e parte delo, por feito, outorgado, sentado, consentido en qualquer maneira nos outorgamos e damos por firme, estabel e valedeiro para sempre so obligacion de todos nosos bees e de cada uno de nos que para elo obligamos de o todo traer, cumplir e agardar, outrosi que rrelevamos ao dicto noso procurador de toda carga de satisdacion obligacion, e fiaduria, su aquela clausula que diz en latin Yudicio sisti yudicato solvi, con todas suas clausulas acustumadas, que foi feita e outorgada ena Villa de Redondela, aos vinte dias do mes de Jullio do ano do nacimento de noso señor Jesuchristo de mill e quatro centos e noventa e quatro anos. Testigos que foron presentes Juan de Sequeiros, criado de mi notario; e Juan Fernandez e Rodrigo das Regadas; e Juan Carneiro e outros. E eu Basco de Bouzas, notario publico da Villa de Redondela e de todos sus terminos e de San Payo de Lodo por lo Reverendissimo señor, meu señorArzobispo e Yglessia de Santiago, e notario ena Yglesia e obispado de Tuy por lo Reverendissimo señor obispo e por la dicta sua Yglesia, que a todo ô que sobre dito he en uno â as ditas testimoiñas presente fui; e con miña mao o escrivi; en fee do qual aqui meu nume e signo puge en testimonio de Verdad que tal he.

E por todos assi os (sobre línea: dictos) poderes logo los dictos Lopo Martiz Arcidiano do Miñor, Vicario do Dean e Cavildo, e Morgued Juan, por si e en nome do dicto Pai Gomes e sus Yglesias; e Rodrigo Afonso en nome do dicto Abad de Vigo, Jacome Perez; e Afonsso de Fornelos, en nome dos vecinos e moradores da villa de Vigo, e Juan Crimenzo en nome dos Vecinos e moradores da Villa de Redondela. Dijero[n] por quanto entreles Dean, e cavildo, e Morgued Juan; e Jacome Perez, e Pai Gomes, eno dicto nome da huna parte; e o dicto Afonso de Fornelos, e Juan Crimenzo eno dicto nome da outra parte contra, e se esperava haver pleitos [tachado: de]Causas, demandas, debates, contendas e questiones de e sobre os panos, e camas de meefresto, e dizimos do pescado, e de pan, e vino, e primicias, que eles entendian litigar huos co outros, que eles dictas partes non atraidos por fuerza ne enducidos por via de engano, mais de sus plazeres e libres votades, por se quitar de perdidas, Custas e danos, e de 
dictos pleitos, causas, demandas, debates, contendas e questiones, e odios, e recores, e disiciones, e males que por o caso delo entre ellos verissimilmente podia sofrecer e sobrevir, e vir a boo amorio tranquilidad e paz e concordia, que ellos justamente conprometian e conprometieron eno Reverendo e manifico señor dò Pedro Beltran, por la gracia de Deus ôbispo de Tuy, que presente estava assi como en seu juis e hombre bueno, Arbitro Arbitrador, e amigable conponedor; para que el Vistos, examinados o que assi decia da una parte e da outra, e quaesquer outros movimentos documentos, e quaesquer outras cousas que por las dictas partes ante el foren presentadas en qualquer maneira que o dicto Reverendo señor ôbispo seu home boo, arbitro arbitrador e amigable conponedor, conjuntamente ou divissa e apartadamente, assi todo se decidir fenecer, determinar e simplemente e de plano, sin estrepitu e figura de juicio, sola facti veritate yns-

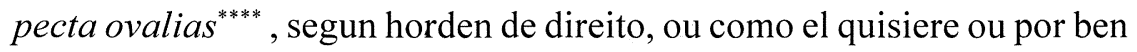
tubere por sentencia ou sentencias difinitiva ou difinitivas Juzgase e mandase, sendo ou estando en dia feriado ou non feriado, as dictas partes presentes ou non presentes; ou hua delas presente e outra ausente, guardadas as rreglas de dereito canonico e civil, ou non gardadas a ius, teniendo as dilazaos e terminos, e cuartando as malicias e sufugios e savendo a verdad dos feitos por quantas vias podese e que podese citar as dictas partes para quaesquer autos dos dictos pleitos bien e assi como se fose Juez hordinario deles, e de cada uno deles, multando e poendo pena ou penas pecuniarias a parte revelde e contumas, como e quantas veces lle prover e fose ben visto, e que da sentesa ou sentenzas ynterlocutorias ou difinitivas, Julgos, Laudos e mandos que el sobre los dichos pleitos causas, contendas, debates e questiones cada una delas pronunciase, descedise e dese, que eles as dictas partes e cada una delas pronuncia e outorgava, prometeron e outorgaron de non apelar, ne suplicar, ne se chamar sobre elo ni parte delo Arvitrio de boo varon, nen de outro Juiz algun, antes que prometia e outorgava prometer e outorgaron de ter cumplir e aguardar todo o que por el dito reverendo señor obispo, seu Juiz Arbitro Arbitrador e Amigable componedor, e qualquer cousa e parte delo fore Julgado, descedido, declarado e determinado, e que prometian e prometeeron outorgavan e outorgaron de non vir contra elo, ni contra parte delo, en juicio ne

**** Examinada la unica verdad del hecho (ovalias = o vel alias?, o cualquiera otra)

"CUADERNOS DE ESTUDiOS GALLEGOS", Tomo XLVII, Fascículo 113, Santiago 2000. 
fora del, so obligacion de sus bees, que para elo expecialmente obligaron, e so pena de mill ducados de ouro, que pagase a parte delo que esto suso dicto, ou parte delo no quisese assi ter Cumplir e agardar, a metade para la camara e fisco de sus Altezas e la otra mitad a la parte agardante e comprente, so pena e postura convencional que cada uno delos assi ponia e puso sobre ssi, e que a dicta pena pagada ou non pagada que este dicto compromiso e sentenza e sentensas e Julgos, Arbitros e mandos que por vigor del dicho señor ôbispo, su hombre bueno, sobre ello en qualquier maneira dese, ficase firmes, estables e valedeiras para sempre, e que davan e deron seu cumplido poder ao dicto Reverendo señor obispo, Arvitro, su juiz, que lo podese ynterpretar e declarar, modificar e enmendar a sentenza ou sentenzas, Julgos e mandos que por el en qualquera manera sobre elo ou parte delo foren dadas, aynda que sobre elo as dictas partes yn juizo la betigase $\mathrm{e}^{* * * *}$ e concedese, żerca do qual todo e cada cousa delo outorgaron o mais forte compromiso e mais firme que de dereito se poder sobre elo notar e ordenar, con consello de letrados, no mudando la sustancia de la Verdad das cousas suso dictas e cada una delas quando quer, e quantas veces necesario fose ou complise para firmeza e validaçon do dicto compromiso; en testimonio do qual outorgaron ende este ynstrumento de compromiso ante mi ho notario publico e testigos a yuso scriptos que foy feito e outorgado, lugar, ano, dia e mes suso dichos, e fecho el dicho Compromiso por las dichas partes, el dicho señor obispo, que presente estava, dijo que el avia bien oido todo lo que las dichas partes avian dicho e visto todos los Poderes que presentavan, e que por tirar a las dichas partes de contenda acettava el dicho Arbitramento e causa, e en la azetando dio Luego yncontinenti hua sentencia ynscriptis, cuyo thenor, de palabra a palabra, es este que se sigue.

Yn Dei nome Amen: por nos dò Pedro Beltran por la gracia de Dios e de la Santa Yglessia de Roma ôbispo de Tuy, JuizArbitro Arbitrador avenidor e Amigable componedor en las causas e negocios, pleitos e contendas avidos ante los honorables e zircunspectos señores, el Dean e cavildo de la Yglessia de Tuy, e Jacome Perez, Clerigo Rector de la Yglessia, parte çencura de Santa Maria de Vigo, e Morgued Juan, Provisor, Rector

$* * * * *$ Litigase

"CUADERNOS DE ESTUDIOS GALLEGOS", Tomo XLVII, Fascículo 113, Santiago 2000. 
da Yglessia de Santa Maria de Revoreda, e Pai Gomez, Rector de la Yglesia de Santiago da dicta Vila de Redondela, da una parte, e os concellos e hombres buenos de las Villas de Vigo, e Redondela, e freigueses, e Parrochianos de las dichas Yglessias, e sus procuradores en sus nombres dellos, sobre e por Razon de los panos, e camas de los finados, que avia e tenia de costumbre de dar a las Yglessias assi hombres como mugeres, al tiempo de su falecimento onde heran Parrochianos; e esso mesmo sobre el dizimo del pescado, e del pan, vino, e primicias e dizimos personales e otras derechuras que los dichos conzejos e freigueses, de las dichas villas de Vigo e Redondela, heran obligados de pagar e pagavan a las dichas Yglessias e rectores delas e a la Yglessia de Tuy assi de derecho Divino como de costumbre en cada un ano: e Visto los Poderes e authoridad de las dichas partes a nos dada, segun en el compromiso entre eles dichas partes, questiones, contendas e debates zelebrado, con jeito e ante publico notario por elas partes outorgado mais largo se conten, al qual nos referimos; e visto sumariamente todas las Ynformaciones scriptas, procesos que ante nos las dichas partes para corroboracion de su justicia cada uno dellos dar e presentar quisese, e las otras alegaciones e palabras dichas e alegadas de la una parte e de la otra, dejado la via e sutileza del derecho, e tomada e eligida la Ygualdad e Razon natural, e por ben de paz, amor, tranquilidad, e concordia de los dichos señores Dean, e cavildo, eAbades de Santa Maria de Vigo, e de Santa Maria de Revoreda, e de Santiago de Redondela, que agora son e seran daqui adelante, e concejos de las dichas villas de Vigo e Redondela, e vecinos e moradores delas e outros qualesquier en los dichos Lugares cohavitantes e estantes por esta nuestra sentencia difinitiva, Arbitrando, aveniendo co acordado e amigablemente entre las dichas partes contenido, mandamos, decernimos, Arvitramos, e por ben tenemos a la dicha Yglessia de Tuy, e las Yglessias, de Vigo, e Redondela, e Revoreda, e los rectores dellas que agora son e seran, para sempre deijen libremente a los Parrochianos de las Villas de Vigo e Redondela, los dichos Paños, e camas, para que dellos agora e para sempre jamais no paguen cosa Alguna a las dichas Yglessias e rectores dellas ni a otras personas alguas en sus no[m]bres, e que los dichos hombres buenos, Freigreses e Parrochianos de las dichas Yglessias, e Parrochianos de Vigo, e Redondela, e Revoreda, por quanto pagava el pescado seco, e no lo pagava fresco, en la Rivera, e avia sobre ello asas divisiones e contendas entrellos e los Abades, se pagavan ben el dizimo o no, que de aqui adelante 
para sempre pagasen de todo pescado, assi de congros como de pescadas, Polvos, sardinas, Vesugos, sardas, Burases, Melcas, bodios, melloas, ollos moles; Cabras, Taiñas; Lagostas e de todo outro qualquer pescado, viñer, assi de Rede, como de Liña; como do trasmallo, do alto, e do baijo; e de sacada, en qualquer maneira que pase do mar en terra, e eno alto, e en barco en qualquera maneira que pase do mar onde quer que pescase, e en outra qualquer maneira, paguen de quinze uno, fresco, ena rriveira, ho qual pescado ha de ser dizimado por lo pesoheiro que for de cada barco, por juramento que cada uno faga Cada año una vez, eno altar cada uno da sua feligresia, de dizimar ben e derectamente de quinze uno, a boa fee de Deus e se mas engano, por dia de San Juan, en deus e suas conciencias, e que quando viren do mar Chamen o dizimeiro en hua das dictas casas que le fuere asignadas por los dizimeiros en a veira dagua do mar, os da rriveira do berves en a casa do berves, e os da rriveira da Ladeira da dicta Villa en a Ladeira, e que os dictos pescados posa sacar seu pescado Libremente quando quijere e por ben tubere, e quanto aos tres Malleiros e sacadores, que se viere de dia con lo pescado que pague ô dizimo ena rriveira, e se vier de noite, que o possa levar a suas casas e dizimarlo nelas e chamar los dizimeiros que Vaan por lo dizimo, e se no fuere luego a tomar seu dizimo quando los llamare, a los que venier [tachado: por]de dia con el pescado que lo pongan en la Rivera e lo dejen alli, e los que vinier con el pescado de noche e levaren a sus casas dos tresmallos e sacada, se non fore el dizimero a la rrivera, que lo faga a saver al dizimero por la mana que va a por el dizimo, e se non fore por el e se perdere que se perda a sua encura: E por quanto los freigueses de la Villa de Redondela, a las devegadas, non poden Traer la sardina e otro pescado a la Villa de Redondela, e la venden en Cangas e en Bayona, e en Vigo, e en outras partes, que de la sardina e pescado que vender fora, se los Abades de Santiago de Redondela e de Santa Maria de Revoreda toviere en los dichos Lugares quien recaude por ellos el dizimo de la tal sardina e pescado, que lle page el dizimo de todo de quinze uno, e se non tubere quen por ellos lo rrecaude que la venda como ha de Costumbre e pague de la tal sardina e pescado que vendere de quinze maravedis, uno, en la Parrochia e A1 Abad de que cada uno for Freigues; e que quanto a los dizimos de pan e vino, e ganado, Lino, Lana; e otras cosas de la tierra que so dizimos prediales, que paguen de diez uno, como sempre pagaron; salvo los Freigueses de fuera de la Villa de Redondela, de las dichas Yglessias de Santa Maria de Revoreda e de San- 
tiago de Redondela, porque quasi todos son Labradores, que estes paguen con el dizimo predial la primicia de quarenta uno del pan: E quanto a los dizimos personales e Ganadios, que todos unos e los otros, paguen como sempre pagaron sub cargo de suas conciencias; assi os de Vigo como os de Redondela, por dos terminos, Uno por natal e outro por San Juan Bautista; e mandamos que se non demanden mais huns aos outros, e non facemos condenacion de Costas por alguas cousas que nos a elo moveron, salvo que cada uno sussiva las que fechas tiene; e que nos el dicho obispo Juez susodicho, por Vigor e poderio del dicho Compromiso e so las penas en el contenidas, Las quales mandamos que peche a la parte que contra lo por nos aqui mandado es e fuere, a la otra parte obediente que lo toviere e cumpliere; e se entre las dichas partes algua duda fuere sobre esto aquí declarado, mandado, Julgado, reservamos que quede en nos que nos lo podamos ynterpretar e declarar, e moderar, e despois de nos nosos sobcesores; e assi lo Juzgamos e mandamos e declaramos, todo assi para todo sobre en estos escriptos: E por eles: P: Ep; Tudens.

E eu Fernan Perez, Canonigo en a dicta Yglesia de Tuy, notario publico Jurado da Ciudad e obispado de Tuy, e notario por quen pasan os autos Capitulares do dicto Cavildo, que a todo o suso dicto en uno co hos dictos testigos presente fui, e este ynstrumento de Compromiso e concordia e sentencia, segun que por ante mi pasou, por miña maa propia escrivi e aqui meu nume e signal puge, segun que por o dicto señor obispo a firmou de seu nume e sinal acustumado; en testimonio de Verdad que tal he, rogado e requerido $=$ En testimonio de Verdad: Fernan Perez, notario. 
1516, Abril, 26. Domingo. Redondela.

Payo Gomez de Sotomayor, rector de la iglesia de Redondela y Arcediano de Miñor, reclama ante los vecinos de la villa de Redondela el cumplimiento de la Sentencia de 1494.

En la Villa de Redondela, dia Domingo, Veinte e seis dias del mes de Abrill de quinientos e dez e seis anos, este dicho dia estando dentro de la Yglesia de Santiago de la dicha Villa de Redondela, estando a la ofrenda, estando ende el Señor Payo Sorrede, Juiz hordinario de la dicha Villa (sobre línea: e su juzgado) por el Reverendissimo e muy magnifico Don Alonso de Fonseca, Arzobispo de Santiago, nuestro señor, e Gonzalo da Verea, e Juan de Cadaval, Rexidores de la dicha Villa; e Pedro Gonzales, e Afonso de Santabaia, Procuradores Generales, muchos vecinos e mareantes de dicha Villa de Redondela, en presencia de mi notario e testigos de yuso scriptos pareciò presente el Reverendo señor Payo Gomez de Sotomayor, Arcediano de miñor en la Yglesia de Tuy, rector de las tres quartas partes concura de la dicha Yglesia, en nombre de la dicha su Yglesia dio e presento esta sentencia desta otra parte contenida, con un mandamiento del muy noble señor Asistente firmado, e con la dicha sentencia e mandamiento pediò e rrequiriò al dicho Juez e rexidores mandase que los dichos vecinos e mareantes de la dicha villa, que presentes estavan, e a los otros ausentes, guardasen e cumpliesen en todo e por todo segun e como en ella se contenia; so las penas en la dicha sentencia e compromiso mandamiento fuesen contenidas, e pediolo por testimonio a mi el dicho notario, estando presentes por testigos Bartholome Gonzales Capellan de la dicha Villa, e Alvaro Daval vecino de la dicha Villa, e otros: Fabian Gorvalan notario publico: 


\section{APÉNDICE II}

\section{SENTENCIA DE 1494. PERSONAS QUE SE CITAN}

\section{POR LA PARTE ECLESIÁSTICA}

PERSONAS Y CANÓNIGOS DE LA IGLESIA DE TUY, os venerables $e$ circunspectos señores:

- Lopo Martiz (o Martínez), Arcidiano de Miñor, Vicario del Deán.

- Pedro Martiz de Montes, Deán.

- Pedro González de Fuentes, Chantre.

- Juan de Santo Domingo, Thesorero.

- Basco de Marzoo, Arcidiano de Montes.

- Morgued Juan.

- Gonzalo Perez.

- Pedro Gonzales.

- Lopo de Cepeda.

- Personas e canónigos da Yglesia de Tuy, en nome da sua Yglesia e mesa Capitular, e tenencia de Vigo, duas partes sincura.

TESTIGOS:

- Fernandez Perez, Alguacil del Obispo.

- Afonsso Lopez, presbítero.

- Gonzalo Afonso, criado del Obispo.

- Gregorio do Barreiro, criado del Obispo.

- e otros.
NOTARIO:

- Jacome Gonzales de Pedroso, Canónigo de la Catedral de Tuy, publico notario por la Santa Authoridad Apostólica e hordinaria.

\section{LOS RECTORES:}

- Morgued Juan, Rector do Beneficio de Santa María de Revoreda, da Vila de Redondela.

- Pai Gomes de Soto (Paigomes), Rector de Santiago de Redondela.

- Jacome Peres, clérigo Abad da Feligresía çencura (?) de Santa María de Vigo.

\section{PROCURADORES:}

- Morgued Juan, por Pai Gomes.

- Rodrigo Afonso, clérigo, por Jacome Peres. 
NOTARIO:

- Juan de Pumar, escrivano e notario publico del Rey e de la Reyna nuestros señores, e notario de la Villa de Vigo e su jurdicion por el muy Reverendíssimo señor Arzobispo e Yglesia de Santiago.
TESTIGOS POR EL RECTOR DE LA

IGLESIA DE VIGO:

- Pedro Collazo.

- Afonso Fernandez.

- Rodrigo Souto.

- Alvaro Vasques.

- e outros.

\section{POR PARTE DE LAS VILLAS}

\section{MAREANTES, VECINOS Y MORADORES DE LA VILLA DE VIGO:}

- Afonso do Outeiro.

- Juan Solteiro.

- Pedro Solteiro.

- Afonso de Guodaran.

- Juan Franco.

- Jacome de Bicedo.

- Pedro Ribeiro.

- Juan Calvo da Ladeira.

PROCURADOR DE LOS VECINOS:

- Afonso de Fornelos, vecino de la villa de Vigo.

TESTIGOS DE LOS VECINOS DE VIGO:

\section{NOTARIO POR LOS VECINOS DE} VIGO:

- Nuño Vasquez, Juiz da dicta vila de - Afonso do Porto, notario e escrivaVigo.

- Pedro Mendez, procurador.

- Ares Perez, clérigo no publico del Rey e Reyna, nuestros señores, enas suas Cortes e en todos los seus Reynos e señorios.

- Afonso Martiz, clérigo de S. Pedro de Sardoma

por ellos e por los outros mariantes vecinos e moradores en esta villa de Vigo 


\section{VECINOS Y MORADORES DE LA VILLA DE REDONDELA:}

$\begin{array}{lll}\text { - Juan Milleiro } & \text { - Basco Preto } & \text { - Alvaro de Lira o Mozo } \\ \text { - Alvaro Salgueiro } & \text { - Gonzalo Milleiro } & \text { - Gonzalo Antre } \\ \text { - Pedro Gonzales Carpinteiro } & \text { Juan Thomas Tezelan } & \text { - Estevo Suares } \\ \text { - Duran de Moscojo } & \text { - Gonzalo de Santa María } & \text { - Juan de Santabaia } \\ \text { - Martino Salgueiro } & \text { - Martino de Nogueira } & \text { - Pedro Buxeiro } \\ \text { - Gonzalo do Casal } & \text { - Pedro Fernandez } & \text { - Gonzalo da Bouza } \\ \text { - Gonzalo de Ramirans } & \text { - Rolan } & \text { - Juan Suares o Mozo } \\ \text { - Afonso Rodriguez } & \text { - Fernan Fragueiro } & \text { - Diego Diz } \\ \text { - Juan Bello } & \text { - Estevo Guiraldez } & \text { - Martin Salgueiro } \\ \text { - Lorenzo de Moos } & \text { - Juan de Mourelle } & \text { - Bartholomeu Suares } \\ \text { - Lorenzo da Quaal } & \text { - Estevo Balan } & \text { - Alvaro de Rouzas } \\ \text { - Gonzalo de Lantano } & \text { - Juan Carneiro } & \text { - Gonzalo Lourenzo } \\ \text { - Juan Crimeco } & \text { - Tharesa de Lavadores } & \text { - Alvaro de Nogueira } \\ \text { - Juan Frances } & \text { - Rodrigo das Regadas } & \\ \text { - Antonio Ferreiro } & \text { - Juan de Guntije } & \\ \text { - Juan Fernandez } & \text { - Gregorio de Junqueiras } & \end{array}$

\section{PROCURADOR DE LOS VECINOS:}

- Juan Cremente (o Cremenco), vecino de la villa de Redondela.

NOTARIO: TESTIGOS DE LOS VECINOS DE

- Basco de Bouzas, notario público da REDONDELA:

Villa de Redondela e de todos sus ter- · Juan de Sequeiros, criado del notario minos e de San Payo de Lodo por lo Basco de Bouzas.

Reverendíssimo señor, meu señor Ar- • Juan Fernandez.

zobispo e Yglesia de Santiago, e no- • Rodrigo das Regadas.

tario ena Yglesia e obispado de Tuy · Juan Carneiro.

por lo Reverendissimo señor obispo • e outros.

e por la dicta sua Yglesia.

DICTA LA SENTENCIA:

- D. Pedro Beltran, Obispo de Tuy, Juiz, Arbitro Arbitrador avenidor e amigable conponedor.

\section{ACTUA COMO NOTARIO:}

- Fernan Perez, Canónigo, notario publico jurado da ciudad e obispado de Tuy, e notario por quen pasan os autos Capitulares do dicto Cavildo.

"CUADERNOS DE ESTUDIOS GALLEGOS", Tomo XLVII, Fascículo 113, Santiago 2000. 


\section{ANEXO DE 1516}

En la iglesia de Santiago de la villa de Redondela:

PRESENTA LA RECLAMACIÓN: TESTIGOS:

- Payo Gomez de Sotomayor, Arce- · Bartholome Gonzales, Capellan de la diano de Miñor, Rector de las tres dicha Villa. quartas partes concura de la dicha - Alvaro da Val, vecino de la villa. Yglesia de Redondela. $\quad$ E otros.

ESTAN PRESENTES:

- Payo Sorrede, Juiz hordinario de la dicha villa e su juzgado por el Reverendissimo e muy magnifico D. Alonso de Fonseca, Arzobispo de Santiago.

- Gonzalo da Verea, Regidor.

- Juan de Cadaval, Regidor.

- Pedro Gonzales, Procurador General.

- Afonso de Santabaia, Procurador General.

- muchos vecinos e moradores de dicha villa de Redondela.

\section{NOTARIO:}

-Fabian Gorvalan, notario publico.

\section{ABREVIATURAS}

A.C.T.: Archivo de La Catedral de Tuy.

A.H.D.T.: Archivo Histórico Diocesano de Tuy.

A.H.D.S.: Archivo Histórico Diocesano de Santiago.

A.H.P.PO.: Archivo Histórico Provincial de Pontevedra.

A.H.D.PO.: Archivo Histórico de la Diputación de Pontevedra.

A.R.G.: Archivo del Reino de Galicia.

A.H.N.: Archivo Histórico Nacional.

A.G.S.: Archivo General de Simancas.

M.P.: Museo de Pontevedra. 